\title{
Phytoplankton responses to atmospheric metal deposition in the coastal and open-ocean Sargasso Sea
}

\author{
Katherine R. M. Mackey 1,2,3* , Kristen N. Buck' , John R. Casey ${ }^{4,5}$, Abigail Cid $^{6}$, Michael W. Lomas $^{4}$, \\ Yoshiki Sohrin ${ }^{6}$ and Adina Paytan ${ }^{1}$ \\ ${ }^{1}$ Institute for Marine Science, University of California at Santa Cruz, Santa Cruz, CA, USA \\ ${ }^{2}$ Woods Hole Oceanographic Institution, Woods Hole, MA, USA \\ ${ }^{3}$ Bay Paul Center for Comparative Molecular Biology and Evolution, Marine Biological Laboratory, Woods Hole, MA, USA \\ ${ }^{4}$ Bermuda Institute of Ocean Sciences, St George's, Bermuda \\ ${ }^{5}$ University of Hawaii at Manoa, Honolulu, HI, USA \\ ${ }^{6}$ Institute for Chemical Research, Kyoto University, Uji, Kyoto, Japan
}

\section{Edited by:}

Sergio Sanudo-Wilhelmy, University of Southern California, USA

\section{Reviewed by:}

Matthew M. Mills, Stanford University, USA

Sergio Sanudo-Wilhelmy, University of Southern California, USA

\section{*Correspondence:}

Katherine R. M. Mackey, Woods Hole Oceanographic Institution, Woods Hole, MA, USA

e-mail:kmackey@whoi.edu
This study investigated the impact of atmospheric metal deposition on natural phytoplankton communities at open-ocean and coastal sites in the Sargasso Sea during the spring bloom. Locally collected aerosols with different metal contents were added to natural phytoplankton assemblages from each site, and changes in nitrate, dissolved metal concentration, and phytoplankton abundance and carbon content were monitored. Addition of aerosol doubled the concentrations of cadmium (Cd), cobalt (Co), copper ( $\mathrm{Cu}$ ), iron (Fe), manganese $(\mathrm{Mn})$, and nickel $(\mathrm{Ni})$ in the incubation water. Over the 3-day experiments, greater drawdown of dissolved metals occurred in the open ocean water, whereas little metal drawdown occurred in the coastal water. Two populations of picoeukaryotic algae and Synechococcus grew in response to aerosol additions in both experiments. Particulate organic carbon increased and was most sensitive to changes in picoeukaryote abundance. Phytoplankton community composition differed depending on the chemistry of the aerosol added. Enrichment with aerosol that had higher metal content led to a 10-fold increase in Synechococcus abundance in the oceanic experiment but not in the coastal experiment. Enrichment of aerosol-derived Co, Mn, and Ni were particularly enhanced in the oceanic experiment, suggesting the Synechococcus population may have been fertilized by these aerosol metals. Cu-binding ligand concentrations were in excess of dissolved $\mathrm{Cu}$ in both experiments, and increased with aerosol additions. Bioavailable free hydrated $\mathrm{Cu}^{2+}$ concentrations were below toxicity thresholds throughout both experiments. These experiments show (1) atmospheric deposition contributes biologically important metals to seawater, (2) these metals are consumed over time scales commensurate with cell growth, and (3) growth responses can differ between distinct Synechococcus or eukaryotic algal populations despite their relatively close geographic proximity and taxonomic similarity.

Keywords: atmospheric metal deposition, colimitation, copper toxicity, incubation, nutrient addition experiment, picoeukaryote, Prochlorococcus, Synechococcus

\section{INTRODUCTION}

The growth of phytoplankton in the ocean is directly influenced by the availability of macro- and micronutrients required for the synthesis of new cells. Compared to micronutrients, macronutrients such as nitrogen $(\mathrm{N})$ and phosphorus $(\mathrm{P})$ are required by cells in higher quantities and at relatively similar ratios across different taxa (Redfield et al., 1963; Bertilsson et al., 2003). In contrast, for trace metal micronutrients, phytoplankton display a broad range of cellular quotas and stoichiometries that can span orders of magnitude (Sunda and Huntsman, 1995b; Bruland et al., 2001). Historically much emphasis has been placed on understanding macronutrient limitation of phytoplankton communities; however, with the development of methods to accurately measure very low metal concentrations in seawater, and improved methods to monitor the growth responses of specific phytoplankton taxa within a mixed population, the effects of trace metals on phytoplankton in the marine environment has become an active field of research (Bruland etal., 1991; Sunda and Huntsman, 1995a,b; Saito et al., 2005; Moore et al., 2006; Paytan et al., 2009).

Atmospheric deposition is a known source of macronutrients to the surface ocean, and the effect of deposition of $\mathrm{N}$ (Prospero and Savoie, 1989; Prospero et al., 1996; Paerl, 1997; Bange et al., 2000; Duce et al., 2008; Mackey et al., 2010), Fe (Duce and Tindale, 1991; Mills et al., 2004; Jickells et al., 2005; Moore et al., 2006), and P (Bergametti et al., 1992; Herut et al., 1999; Mackey et al., 2007, 2012) on phytoplankton growth have been documented. While atmospheric deposition is known to supply other biologically important trace metals to the surface ocean, the effect of these trace micronutrients on resident phytoplankton communities remains largely unexplored. A wealth of information is available about the trace metal content of atmospheric aerosols 
collected at locations around the globe (Duce et al., 1991; Chen et al., 2008; Trapp et al., 2010), and anthropogenic sources appear to have higher fractional metal solubility (and potentially bioavailability) than mineral sources (Sedwick et al., 2007; Sholkovitz et al., 2010, 2012). For some locations, atmospheric deposition may be the main source of certain biologically important metals, such as in the open ocean during seasonal stratification where other potential metal sources like upwelling and discharge from rivers and groundwater are scarce.

There is mounting evidence that the different metal requirements among diverse phytoplankton taxa help determine their distribution, abundance, and activity in the ocean, highlighting a potentially important ecological role for atmospheric metal deposition. For example, addition of Sahara aerosol stimulates $\mathrm{N}_{2}$ fixation by diazotrophs in the North Atlantic by providing Fe and P (Mills et al., 2004). Enzymatic requirements for specific metal cofactors can also lead to niche-defining metal requirements for certain groups of phytoplankton. For example, in contrast to eukaryotes, the cyanobacteria Synechococcus and Prochlorococcus have an absolute cobalt (Co) requirement for which $\mathrm{Zn}$ cannot substitute (Sunda and Huntsman, 1995a; Saito et al., 2002), suggesting their distributions in the ocean could be limited by Co availability (Saito and Moffett, 2001; Saito et al., 2005). On the other hand, different toxicity thresholds may influence phytoplankton community composition when metal concentrations are high. Variable toxicity thresholds to copper $(\mathrm{Cu})$ and other trace metals in picophytoplankton has been suggested to influence how phytoplankton community structure responds to atmospheric deposition in the North Atlantic Ocean (Mann et al., 2002), Red Sea (Paytan etal., 2009), and western North Pacific Ocean (Guo etal., 2011). The unique metal requirements and toxicity thresholds of different phytoplankton taxa are therefore important in determining whether segments of the overall population will respond to trace metal availability from atmospheric metal deposition.

The Sargasso Sea is an oligotrophic region in the western North Atlantic Ocean where (co)limitation between macronutrients and trace metals has been identified (Mills et al., 2004; Moore et al., 2008). While atmospheric deposition relieves P and Fe (co)limitation in the Sargasso (Mills et al., 2004), atmospheric $\mathrm{N}$ input may have a smaller influence on phytoplankton growth. Michaels et al. (1993) showed that the amount of $\mathrm{N}$ contributed by wet deposition is negligible compared to the overall $\mathrm{N}$ budget for the region, although it could be important under specific circumstances, such as after large rain events that are followed by calm conditions. Under these conditions, the $\mathrm{N}$-rich rainwater could be retained in the surface ocean for sufficient time to be exploited by phytoplankton before getting diluted through mixing.

Less is known about the effect of dry deposition on phytoplankton in the region and particularly the response of phytoplankton to $\mathrm{N}$ and trace metals from this source. The Sargasso Sea receives a mixture of mineral dust from the Sahara Desert and anthropogenic aerosols from North America (Prospero et al., 1996), and receives a moderate amount of dry deposition relative to other open ocean waters (Mahowald et al., 2005). If atmospheric dry deposition provides a similar magnitude of $\mathrm{N}$ as wet deposition in the region, as is the case for other areas in the Western Atlantic (Paerl,
1997), then it is likewise doubtful that aerosol $\mathrm{N}$ plays a major role in supporting productivity in the Sargasso Sea throughout the year.

In the Sargasso Sea a spring bloom occurs from March to April, when increased irradiance throughout the spring warms surface waters, leading to stratification and trapping relatively high levels of nitrate $\left(\mathrm{NO}_{3}^{-}\right)$from winter mixing above the critical depth. During the bloom, Fe availability affects both the rate of $\mathrm{NO}_{3}^{-}$ consumption and the photosynthetic response to changing light regimes (Moore et al., 2006). Rapid phytoplankton growth during the bloom could lead to higher demands for metal micronutrients, and indeed the extent of atmospheric Fe deposition is believed to influence bloom dynamics at some locations in the Sargasso Sea (Moore et al., 2006). However, in light of the knowledge that atmospheric deposition can be an important source of other biologically important metals to remote ocean locations, it seems feasible that deposition of these metals could also shape phytoplankton communities through selective fertilization and toxicity in the Sargasso Sea during the bloom. The greater input of anthropogenic aerosol sources during the spring supports this possibility, because these aerosols generally have higher metal solubility compared to Sahara dust, which dominates during the summer. The responses of phytoplankton to atmospheric metal deposition during the bloom could differ over relatively small spatial scales based on distance from land, depending on the ubiquity and magnitude of terrestrial metal sources such as runoff, groundwater, fluvial discharge, sediment resuspension, mixing, and upwelling.

The goal of this study was to compare the growth responses of phytoplankton in the open-ocean Sargasso Sea and coastal Bermuda (Figure 1) to atmospheric deposition during the spring bloom, with an emphasis on the effect of aerosol metal content. To address this goal, we conducted incubation experiments with distinct locally collected aerosols that had different levels of biologically important metals. We monitored changes in phytoplankton growth and trace metal concentration, and show that metals were drawn down more sharply in the open ocean as compared to the coastal site. Moreover, phytoplankton subpopulations responded differently to aerosol additions between the two sites, likely due to different trace metal requirements and metal speciation. We explore the responses of phytoplankton to metal availability in the coastal and open, and discuss how atmospheric deposition may influence biogeochemical cycles by providing trace metals to metal limited phytoplankton communities.

\section{MATERIALS AND METHODS AEROSOL COLLECTION AND ANALYSIS}

Weekly integrated (over $\sim 7$ day periods) atmospheric particulate samples were collected at the Tudor Hill observatory in southwestern tip of Bermuda on top a $15 \mathrm{~m}$ tall sampling tower as described in (Arimoto et al., 1995; Sholkovitz and Sedwick, 2006). Air was pumped and aerosols collected for all wind directions except when the wind traversed Bermuda directly [contingent on wind speed $(>1 \mathrm{~m} / \mathrm{s})$ and direction $\left(210-315^{\circ}\right)$ ], thereby eliminating potentially contaminating air masses from local emissions on the island. Aerosol samples were collected on acid cleaned quartz filters and stored frozen until analysis. The soluble metal content of each aerosol sample was determined following dissolution as described 


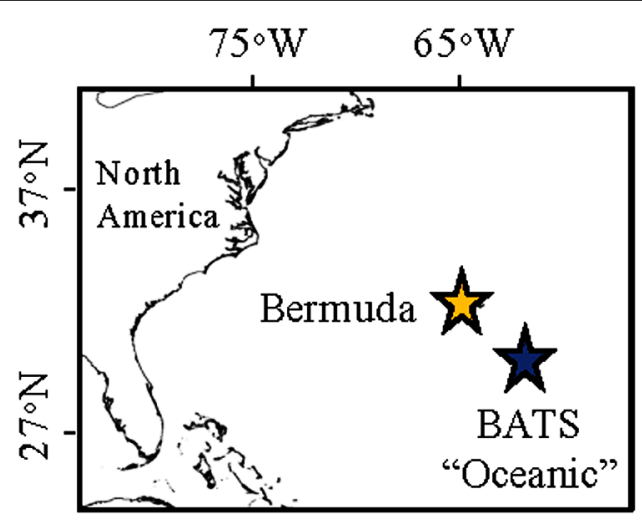

FIGURE 1 | Map showing the location of the Bermuda Atlantic Time-series Station (BATS) where the oceanic incubation water was

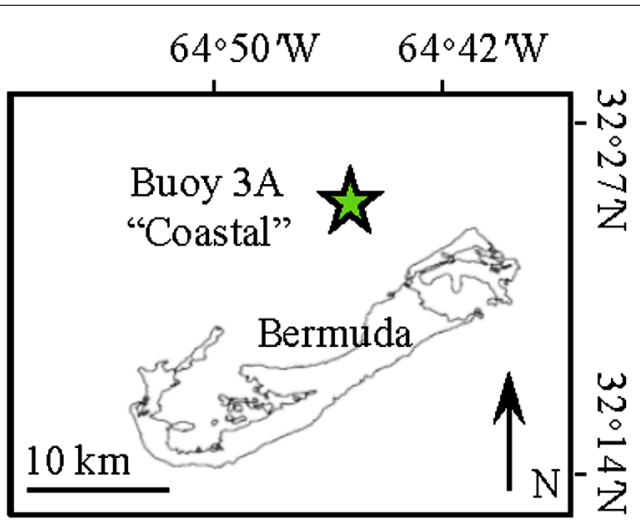

collected (blue star) and Buoy 3A where the coastal water was collected (green star). Orange star in the left panel shows the location of Bermuda. in Buck et al. (2006). A 100 mL volume of Milli-Q water was passed using vacuum filtration through a $47 \mathrm{~mm}$ diameter subsection of the sample filter, and the filtrate was acidified to ( $\mathrm{pH} 2)$ using ultrapure trace metal grade nitric acid (Optima). Metal concentrations in the filtrate were measured on an Element 2 inductively coupled plasma-mass spectrometer (ICP-MS). Scandium and Rhodium were added to each sample for internal standardization. Mixed trace metal standards were prepared over a range of concentrations (1-100 ppb) from concentrated certified trace metal stock solutions diluted in $2 \%$ nitric acid. The mass of total suspended particles (TSP) on the filter was calculated from the aluminum (Al) content, assuming $10 \%$ solubility and an Al:TSP ratio of 0.101 , which is typical for Bermuda aerosols (Prospero et al., 1996).

\section{INCUBATION EXPERIMENTS}

Nutrient and aerosol addition incubation experiments were conducted in April 2010 with surface water collected at open ocean ("oceanic") and coastal locations in the Sargasso Sea (Figure 1). The oceanic experiment used water collected at the Bermuda Atlantic Time-series Station (BATS; $\left.31^{\circ} 40^{\prime} \mathrm{N}, 64^{\circ} 10^{\prime} \mathrm{W}\right)$. The coastal experiment used water collected at Buoy $3 \mathrm{~A}\left(32^{\circ} 24.531^{\prime} \mathrm{N}\right.$, $64^{\circ} 44.769^{\prime} \mathrm{W}$ ) located within the Bermuda platform, inside of the Rim Reef Zone that encircles the waters north of the island. In 2010, deep mixing to 300-400 m occurred at BATS during February, and stratification began to occur in March. By April at the time of our sampling the mixed layer depth had shoaled to $\sim 80 \mathrm{~m}$, though stratification was punctuated by periods of deeper mixing down to $\sim 120 \mathrm{~m}$ in the weeks leading up to our sampling. For both experiments, water was collected on windy days reaching 4-6 on the Beaufort scale.

Water was transported back to the Bermuda Institute of Ocean Science (BIOS), where both experiments were conducted. Water was dispensed into acid cleaned, sample rinsed $500 \mathrm{~mL}$ clear polycarbonate incubation bottles, and treatments were made as described below (12 bottles per treatment). Bottles were incubated under shading material (50\% light attenuation) in a tank with circulating seawater to maintain surface ocean temperature. Three bottles from each treatment were collected at each time point, including time zero ( $\mathrm{t} 0$ ), which was processed immediately and completed within $1 \mathrm{~h}$ after the nutrient or aerosol treatments were added, as well as after 1, 2, and 3 days of incubation. Samples for monitoring phytoplankton growth and nutrient and metal analysis were collected as described below.

In each experiment, treatments included inorganic nutrient additions, aerosol additions, and controls (no nutrient or aerosol additions). Inorganic nutrient treatments included single addition or a combination of $0.2 \mu \mathrm{M} \mathrm{PO}_{4}^{3-}, 10 \mu \mathrm{M} \mathrm{NO}_{3}^{-}$, and $5 \mathrm{nM} F$ The following inorganic nutrient treatments were included: $\mathrm{PO}_{4}^{3-}$ alone, $\mathrm{NO}_{3}^{-}$alone, $\mathrm{Fe}$ alone, and $\mathrm{PO}_{4}^{3-}, \mathrm{NO}_{3}^{-}$, and $\mathrm{Fe}$ together (hereafter referred to as the "N,P,Fe" treatment). For the aerosol treatments, we selected two aerosol samples (Aerosol 1 and Aerosol 2 ) based on the chemical composition of the dissolved fraction in each sample as previously determined in the lab (see Figure 2; Table 1). Each type of aerosol was added at two concentrations, for a total of four aerosol treatments. The higher deposition treatments (referred to as "Aerosol 1" and Aerosol 2" for simplicity) simulated a concentration of aerosol that would occur in the surface ocean upper $10 \mathrm{~m}$ mixed layer following 10 days of deposition after a moderately strong deposition event typical of the central North Atlantic $\left(20 \mathrm{~g} \mathrm{~m}^{-2} \mathrm{y}^{-1}\right)$. Lower aerosol concentration treatments were also tested, simulating a typical annual average deposition rate for the Sargasso Sea near Bermuda $\left(2 \mathrm{~g} \mathrm{~m}^{-2} \mathrm{y}^{-1}\right.$; Mahowald etal., 2005), and these treatments are referred to as "Aerosol 1 low" and "Aerosol 2 low" to differentiate them from the high treatments.

\section{PHYTOPLANKTON GROWTH RESPONSES}

Aliquots $(1.5 \mathrm{~mL})$ for flow cytometry were preserved with $75 \mu \mathrm{L}$ $10 \%$ paraformaldehyde solution, incubated in the dark at room temperature for $10 \mathrm{~min}$, and frozen at $-80^{\circ} \mathrm{C}$ until analysis. Samples were analyzed on an Influx flow cytometer (BD Biosciences, Franklin Lakes, NJ, USA) triggering on forward angle light scatter (FSC). Cell abundances and particulate organic carbon (POC) contribution were determined for each group (Figures $4 \mathrm{~A}-\mathbf{H}$ ). Populations of Synechococcus and eukaryotic algae were identified in all samples and discriminated based on their characteristic fluorescence and scattering properties (Figure 4I). Two subpopulations of eukaryotic algae lacking orange/yellow (580/20 nm 


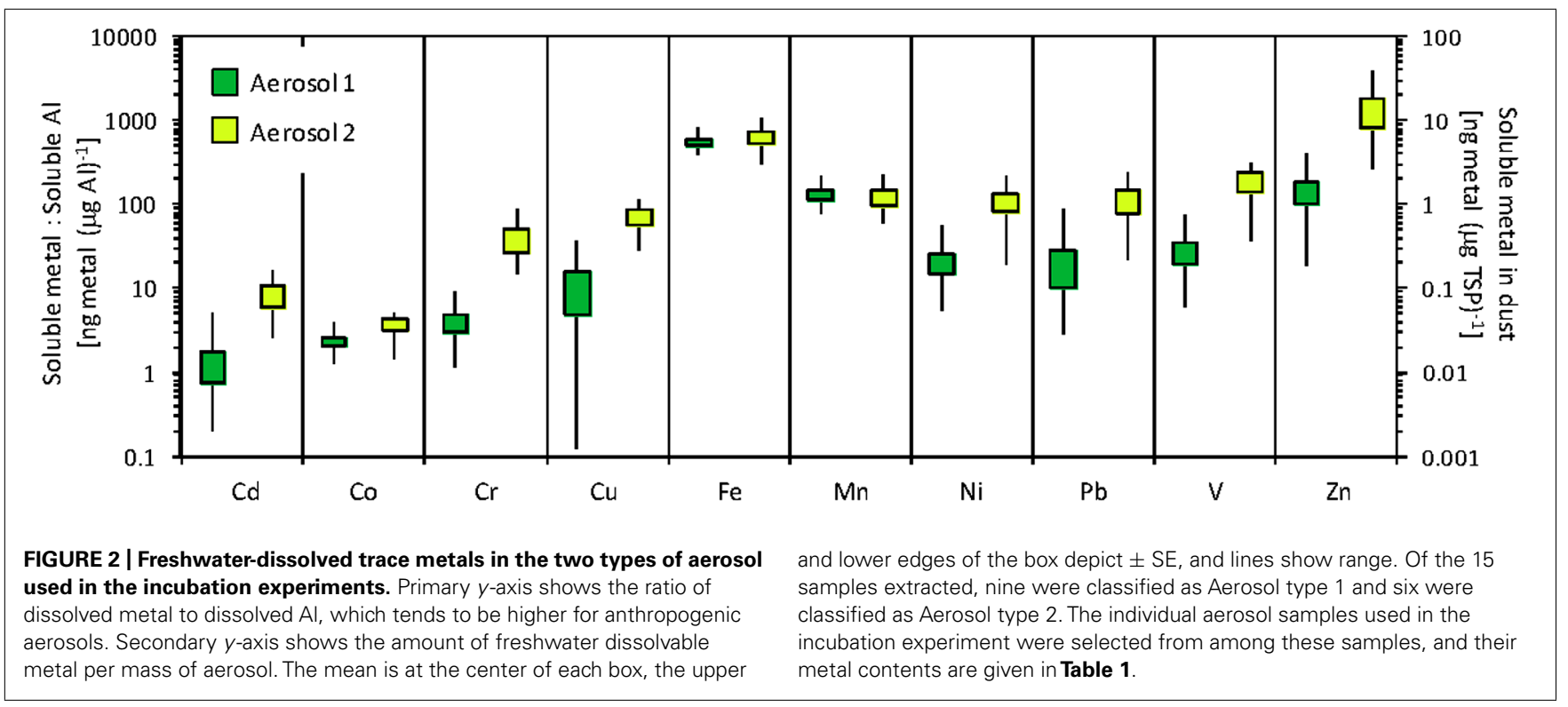

Table 1 | Freshwater-dissolved trace metal content of the aerosol samples used in the incubation experiment.

\begin{tabular}{lll}
\hline Metal & Aerosol $\mathbf{1}$ (ng metal/ $\boldsymbol{\mu g}$ TSP) & Aerosol $\mathbf{2}$ (ng metal/ $\boldsymbol{\mu}$ TSP) \\
\hline $\mathrm{Cd}$ & 0.051 & 0.123 \\
$\mathrm{Co}$ & 0.026 & 0.051 \\
$\mathrm{Cr}$ & 0.094 & 0.508 \\
$\mathrm{Cu}$ & 0.361 & 1.057 \\
$\mathrm{Fe}$ & 8.100 & 6.711 \\
$\mathrm{Mn}$ & 1.786 & 1.864 \\
$\mathrm{Ni}$ & 0.571 & 1.745 \\
$\mathrm{~Pb}$ & 0.885 & 1.505 \\
$\mathrm{~V}$ & 0.737 & 2.766 \\
$\mathrm{Zn}$ & 4.075 & 10.95
\end{tabular}

bandpass) autofluorescence were also detected in both coastal and oceanic samples, and were discriminated by FSC-H amplitude (eukaryotic algae 3A and 3B, herein). Prochlorococcus was found only in very low abundances in coastal waters, and was a minor community member in terms of cell abundance and POC contribution; accordingly, we focus our discussion on the eukaryote and Synechococcus subpopulations. The low Prochlorococcus abundances are not likely due to the low autofluorescence of these cells being below detection limits of the flow cytometer, since the same protocol and flow cytometer used to enumerate these cells for routine monitoring at BATS was employed in this study. Possible explanations for the low Prochlorococcus abundances are explored in the discussion. Quality flagging during batch processing was defined to reject gated populations which failed the following criteria: events $<100$, kurtosis $<0$, skewness $>|5|$, median absolute deviation $>50 \%$. The cellular carbon (C) content of Synechococcus and picoeukaryote cells during each experiment was determined based on forward scatter signal following Casey et al. (2012). The contribution of these cells to particulate organic $\mathrm{C}$ was determined by multiplying cellular $\mathrm{C}$ content by cell abundance.

For chlorophyll $a$ (chl $a$ ) analysis, $250 \mathrm{~mL}$ seawater was filtered through GFF filters (Whatman). Filters were frozen at $-20^{\circ} \mathrm{C}$ until analysis. Chl a concentration was determined fluorometrically following $24 \mathrm{~h} 90 \%$ acetone extraction at $-20^{\circ} \mathrm{C}$. Fluorescence was measured on an AU10 fluorometer (Turner Designs) calibrated with chl $a$ standard solution derived from Anacystis nidulans cyanobacteria following (JGOFS, 1994).

\section{SEAWATER NITRATE AND TRACE METAL ANALYSES}

Seawater samples for nutrient analysis were collected by syringe filtration $\left(0.45 \mu \mathrm{m}\right.$ PES) and stored frozen until analysis. $\mathrm{NO}_{3}^{-}$ concentrations were measured on a flow injection autoanalyzer (FIA, Lachat Instruments Model QuickChem 8000) using standards prepared in Milli-Q water. Blanks were prepared in aged, low nutrient seawater. The detection limit based on three-times the standard deviation of the blanks was determined to be $0.1 \mu \mathrm{M}$ for $\mathrm{NO}_{3}^{-} \cdot \mathrm{PO}_{4}^{3-}$ was measured as described above for $\mathrm{NO}_{3}^{-}$, with a detection limit of $\sim 0.01 \mu \mathrm{mol} \mathrm{L}{ }^{-1}$, and is discussed in Mackey et al. (2012). We report here only $\mathrm{NO}_{3}^{-}$(including trace amounts of nitrite and ammonium) data as growth in the $\mathrm{PO}_{4}^{3-}$ treatment was not appreciably different than controls in any of the experiments.

To measure trace metals dissolved in seawater, $50 \mathrm{~mL}$ subsamples were collected by syringe filtration $(0.2 \mu \mathrm{m}$ PES) in a laminar flow hood. For simplicity we only report data for Aerosol 2 "high" in comparison to the control and N,P,Fe treatments, as phytoplankton growth indicated that trace metal limitation may have been relieved by this treatment (see below). Samples were acidified with four drops of ultrapure trace metal grade hydrochloric acid (Optima) to $\mathrm{pH}<2$. Trace metals were separated from the major seawater ions and pre-concentrated by a factor of $\sim 3$ using NOBIAS Chelate PA-1, a non-swelling resin with ethylenediaminetriacetic acid functional groups (Sohrin et al., 2008; Sohrin 
and Bruland, 2011). Metal concentrations in the eluant were determined on an Elan DRC II ICP-MS. Metal drawdown was quantified by calculating the difference between mean concentrations at $t 0$ and $t 3$, and uncertainty in the difference was calculated by propagating the error according to the standard error propagation formula: $(A \pm a)-(B \pm b)=(A-B) \pm \sqrt{ }\left(a^{2}+b^{2}\right)$.

Statistical significance was evaluated at $p<0.05$ and $p<0.10$ performing a one-way analysis of variance (ANOVA) to detect differences between the mean values, followed by Dunnett's test to compare control values with other treatments for each experiment.

\section{COPPER SPECIATION MEASUREMENTS}

Copper speciation measurements were performed at two analytical windows in the control, Aerosol 1, and Aerosol 2 treatments in the coastal and oceanic experiments. Samples were collected at t0, as well as t3. To obtain a sufficient volume of sample, $200 \mathrm{~mL}$ of sample water was combined from each of the three replicate bottles at each time point. The composite sample was passed through an in-line cartridge filter $(0.45 \mu \mathrm{m}$, Osmonics, PTFE membrane) using a peristaltic pump, and stored frozen $\left(-20^{\circ} \mathrm{C}\right)$ until analysis.

Copper speciation was measured using competitive ligand exchange- adsorptive cathodic stripping voltammetry (CLEACSV) using the added ligand salicylaldoxime (SA) as described previously (Buck and Bruland, 2005; Buck et al., 2010). Briefly, thawed speciation samples were buffered with $7.5 \mathrm{mM}$ ammonium-borate buffer (final $\mathrm{pH}$ 8.2, NBS scale), titrated with 0-15 $\mathrm{nM}$ of dissolved $\mathrm{Cu}$ and allowed to equilibrate for at least $2 \mathrm{~h}$ before the addition of SA as the competing ligand. Following an additional equilibration time of $15 \mathrm{~min}$, each vial in the titration was analyzed by ACSV. Two analytical windows were employed in analyses using SA additions of $2.5 \mu \mathrm{M}$ and $0.5 \mu \mathrm{M}$. Titration data were interpreted using van den Berg/Ružic (Ružic, 1982; van den Berg, 1982) and Scatchard (Scatchard, 1949) linearization techniques, and the results from both linearizations were averaged to provide final ligand concentrations and conditional stability constants, with standard deviations of these values reflecting the variability between interpretation method output for the titrations (Buck et al., 2010). One ligand class was determined within each analytical window with the ligand determined in the higher analytical window denoted "stronger" while the lower analytical window defined the "weaker" ligand class. Free, hydrated $\mathrm{Cu}^{2+}$ concentrations were determined using the higher analytical window data, which better represents the ambient speciation, following the calculations presented by Moffett and Dupont (2007).

\section{RESULTS}

\section{AEROSOLS CHEMISTRY}

To identify unique aerosol "types" to be used in the incubation experiment, the concentration of dissolved trace metals in MilliQ water was measured in aerosol samples collected in Bermuda. Of the 15 samples analyzed, two qualitatively defined types of aerosol were identified based on the relative amounts of dissolved trace metals in the sample (Aerosol type $1 n=9$; and Aerosol type $2 n=6$ ). The concentration ranges for each metal in these aerosol samples are shown in Figure 2. We selected individual filters from each of these types to use as the aerosol additions in the incubation experiments. Aerosol 1 was collected over November 2-9, 2009 and Aerosol 2 was collected over September 28, 2009 to October 12, 2009 and October 26, 2009 to November 2, 2009. Aerosol 2 had relatively higher amounts of dissolved $\mathrm{Cd}, \mathrm{Cr}, \mathrm{Cu}$, nickel (Ni), $\mathrm{Pb}, \mathrm{V}$, and $\mathrm{Zn}$ than Aerosol 1, while dissolved Fe and manganese $(\mathrm{Mn})$ concentrations were similar between the two types (Table 1). Aerosol 2 had twice as much dissolved Co (0.051 ng Co $\left(\mu \mathrm{g} \mathrm{TSP}^{-1}\right)$ as Aerosol 1 (0.026 ng Co $\left.(\mu \mathrm{g} \mathrm{TSP})^{-1}\right)$.

Vanadium (V) enrichment relative to $\mathrm{Al}$ has been used to identify anthropogenic influence in aerosol samples, because anthropogenic aerosols are enriched in $\mathrm{V}$ while the main source of $\mathrm{Al}$ in aerosols is from the earth's crust (Chen and Duce, 1983). In this study, the ratio of dissolved $\mathrm{V}$ to dissolved $\mathrm{Al}$ was higher in Aerosol type $2\left(192 \pm 49 \mathrm{ng} \mathrm{V}(\mu \mathrm{g} \mathrm{Al})^{-1}\right)$ than Aerosol type $1\left(27 \pm 7 \mathrm{ng} \mathrm{V}(\mu \mathrm{g} \mathrm{Al})^{-1}\right)$, which indicates a higher fraction of anthropogenic material in Aerosol type 2. The higher content of other dissolved trace metals in Aerosol type 2 (Figure 2) is also consistent with greater anthropogenic influence.

\section{PHYTOPLANKTON GROWTH}

The initial chl $a$ concentration in the oceanic experiment was $0.17 \mathrm{mg} \mathrm{m}^{-3}$. The greatest increases in chl $a$ after 3 days of incubation were observed in the N,P,Fe, Aerosol 2, and Aerosol 1 treatments, reaching $4.7,2.5$, and $2.0 \mathrm{mg} \mathrm{m}^{-3}$, respectively (Figure 3A). All other treatments showed levels close to the control (range $0.50-0.69 \mathrm{mg} \mathrm{m}^{-3}$ in day 3 ). In the coastal experiment, the initial chl $a$ concentration was $0.35 \mathrm{mg} \mathrm{m}^{-3}$, and the largest increases were observed for the N,P,Fe and Aerosol 2 treatments, which reached 2.7 and $1.3 \mathrm{mg} \mathrm{m}^{-3}$, respectively (Figure $3 \mathbf{B}$ ). All other treatments had levels close to the control (range 0.21$0.59 \mathrm{mg} \mathrm{m}^{-3}$ ). Because substantial growth responses were only observed in the "N,P,Fe" and both the "Aerosol 1 high" and "Aerosol 2 high" treatments, the remainder of our discussion focuses on these treatments, along with the controls for each experiment. For simplicity, we refer to these treatments as "Aerosol 1" and "Aerosol 2 " as described above.

Initial cell abundances, cellular carbon content and fluorescence were statistically indistinguishable between treatments for each population and subpopulation reported $(p>0.05)$. In the oceanic experiment, the initial phytoplankton population was dominated by Synechococcus $\left(31.7 \pm 0.5 \times 10^{3}\right.$ cells $\mathrm{mL}^{-1}$; Figure 4A), followed by picoeukaryotes $\left(8.6 \pm 0.2 \times 10^{3}\right.$ cells $\mathrm{mL}^{-1}$; Figures 4C,E). Synechococcus abundance increased 10 -fold

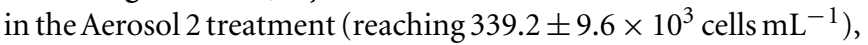
and approximately fourfold in the Aerosol $1\left(135.5 \pm 7.5 \times 10^{3}\right.$ cells $\left.\mathrm{mL}^{-1}\right)$ and N,P,Fe treatments $\left(96.0 \pm 1.1 \times 10^{3}\right.$ cells $\left.\mathrm{mL}^{-1}\right)$. Two subpopulations of eukaryotes, $3 \mathrm{~A}$ and $3 \mathrm{~B}$, were initially present at $5.6 \pm 0.2$ and $1.2 \pm 0.1 \times 10^{3}$ cells $\mathrm{mL}^{-1}$, respectively. Total picoeukaryote growth of both subpopulations responded most strongly in the N,P,Fe treatment, increasing sixfold $\left(51.9 \pm 1.3 \times 10^{3}\right.$ cells $\left.\mathrm{mL}^{-1}\right)$. The Aerosol 1 and Aerosol 2 treatments also resulted in increased total picoeukaryote growth,

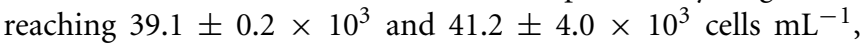
respectively. Eukaryotic subpopulations $3 \mathrm{~A}$ and $3 \mathrm{~B}$ reached the highest concentrations at $\mathrm{t} 3$ in the N,P,Fe treatment $(20.1 \pm 1.6$ and $30.0 \pm 0.7 \times 10^{3}$ cells $\mathrm{mL}^{-1}$, respectively). While subpopulation $3 \mathrm{~A}$ responded identically between Aerosol 1 and Aerosol 

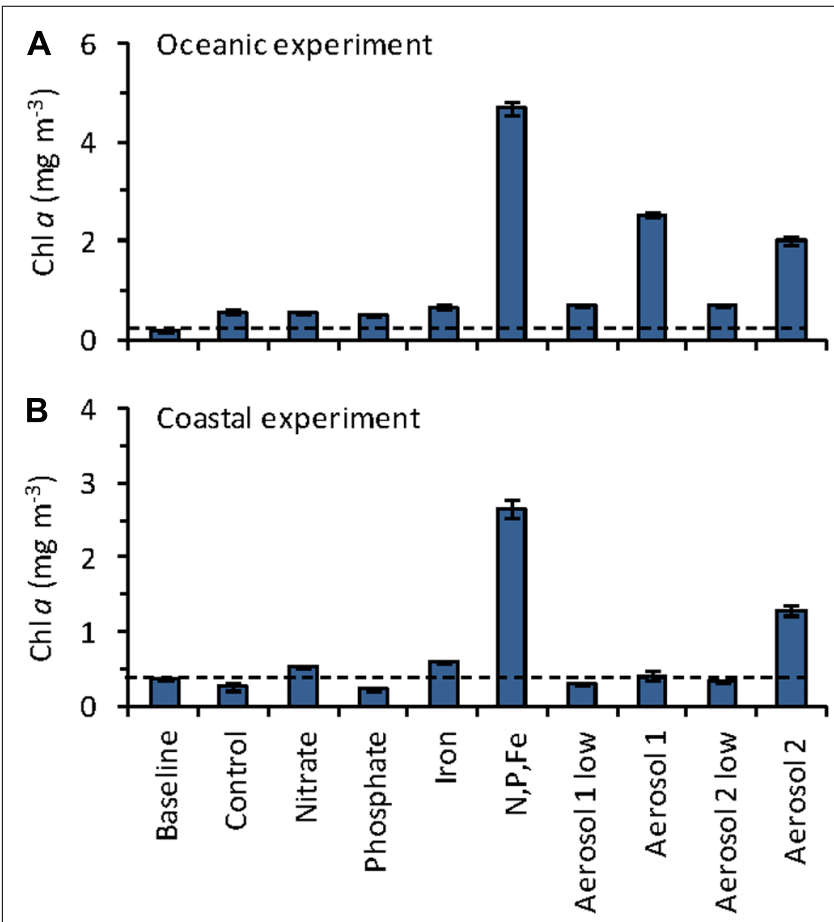

FIGURE 3 | Mean chlorophyll a concentrations on day 3 of the (A) oceanic, and (B) coastal incubation experiments. Dashed line shows the initial (baseline) chl a level. Error bars show standard error for triplicate bottles.

2 treatments $\left(16.5 \pm 1.2\right.$ and $17.0 \pm 2.9 \times 10^{3}$ cells $\mathrm{mL}^{-1}$, respectively; $p=0.88$ ), subpopulation $3 \mathrm{~B}$ concentrations were significantly higher in Aerosol $1\left(23.5 \pm 0.8 \times 10^{3}\right.$ cells $\left.\mathrm{mL}^{-1}\right)$ than Aerosol $2\left(10.8 \pm 1.6 \times 10^{3}\right.$ cells $\left.\mathrm{mL}^{-1} ; p=0.006\right)$.

The initial cellular $\mathrm{C}$ content in the oceanic experiment for Synechococcus was $223 \pm 4 \mathrm{fg} \mathrm{C}$ cell $^{-1}$. Both Aerosol 1 and Aerosol 2 treatments resulted in decreased carbon quotas at the end of the incubations $\left(205 \pm 7.5\right.$ and $181 \pm 6.6 \mathrm{fg} \mathrm{C}$ cell $^{-1}$, respectively) while $\mathrm{N}, \mathrm{P}, \mathrm{Fe}$ treatment resulted in the highest cellular quotas $\left(250 \pm 1.1 \mathrm{fg} \mathrm{C} \mathrm{Cell}^{-1}\right)$. Carbon quotas for eukaryotic subpopulations $3 \mathrm{~A}$ and $3 \mathrm{~B}$ increased significantly throughout all incubation treatments (initially $829 \pm 3.5$ and $2953 \pm 11 \mathrm{fg} \mathrm{C}$ cell $^{-1}$ ). Subpopulation $3 \mathrm{~A}$ increased similarly, in the control, Aerosol 2, and $\mathrm{N}, \mathrm{P}, \mathrm{Fe}$ treatments to $1019 \pm 4.0 \mathrm{fg} \mathrm{C} \mathrm{cell}^{-1}$ at $\mathrm{t} 3$, each significantly higher than Aerosol 1 (963 $\left.\pm 5.2 \mathrm{fg} \mathrm{C} \mathrm{cell}^{-1} ; p<0.05\right)$. Subpopulation $3 \mathrm{~B}$ also increased significantly but less than subpopulation $3 \mathrm{~A}$ for all treatments $\left(2809 \pm 61 \mathrm{fg} \mathrm{C} \mathrm{cell}^{-1}\right)$ compared to the control $3140 \pm 27 \mathrm{fg} \mathrm{C}$ cell $\left.^{-1} ; p<0.05\right)$.

The initial amount of POC contributed by Synechococcus and picoeukaryotes was $15.3 \pm 0.6 \mathrm{mg} \mathrm{C} \mathrm{m}^{-3}$, and by the end of the experiment the control remained close to this level (16.7 $\pm 0.5 \mathrm{mg} \mathrm{C} \mathrm{m}^{-3}$; Figure 4G). Aerosol 1 and Aerosol 2 treatments caused similar increases in POC, reaching $143 \pm$ $4.4 \mathrm{mg} \mathrm{C} \mathrm{m}^{-3}$ and $136 \pm 17.8 \mathrm{mg} \mathrm{C} \mathrm{m}^{-3}$ by t3, respectively. The greatest increase was observed in the N,P,Fe treatment, where POC increased to $204 \pm 29.3 \mathrm{mg} \mathrm{C} \mathrm{m}^{-3}$. As reflected in cell abundance data, the highest biomass increases for Synechococcus were 10-fold for Aerosol 2 treatment. Although total eukaryotic algae biomass
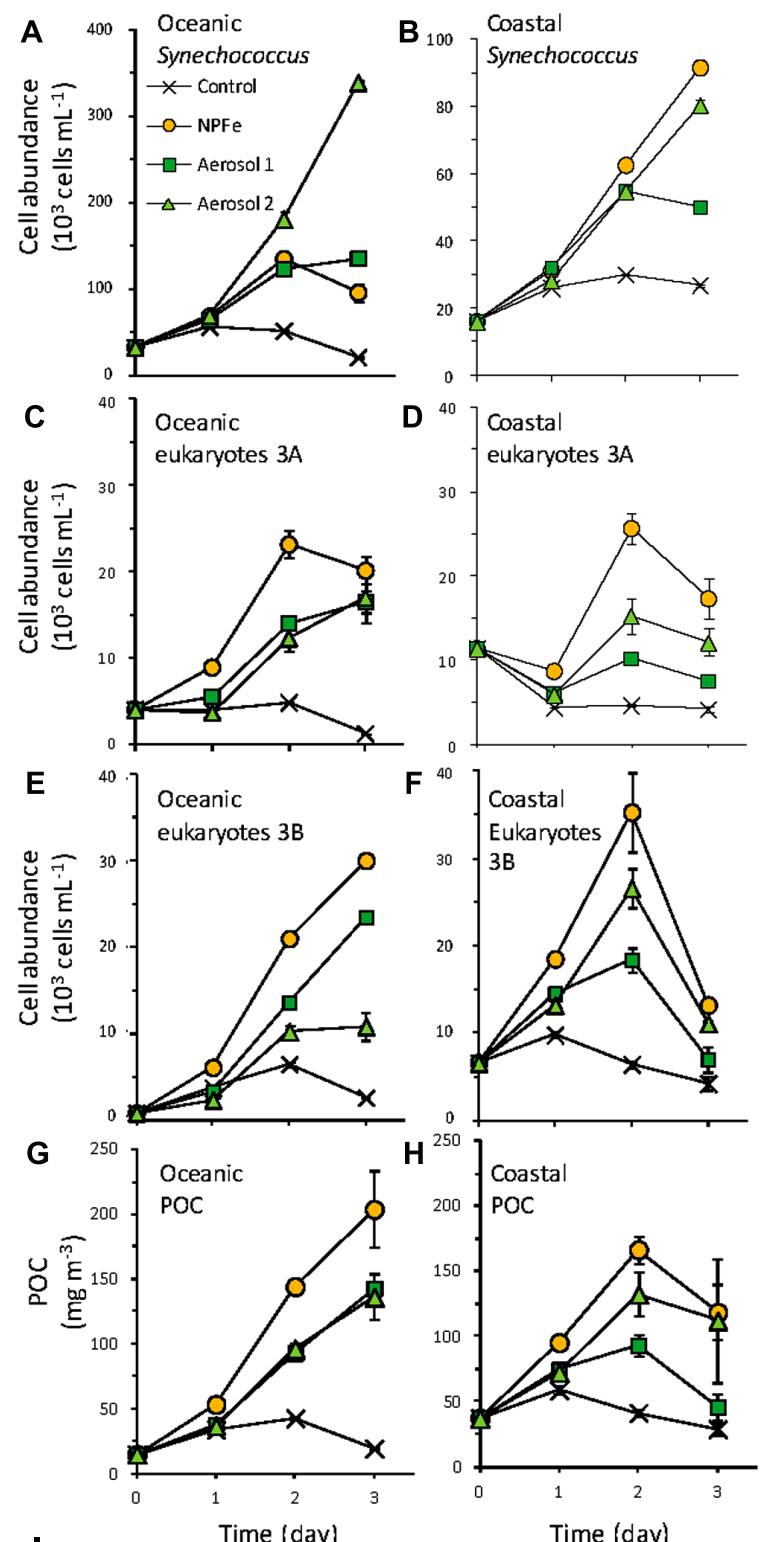

I



FIGURE 4 | Cell growth for (A,B) Synechococcus (C,D) picoeukaryote subpopulation $3 A$, and $(E, F)$ picoeukaryote subpopulation $3 A$ during the oceanic $(A, C, E)$ and coastal $(B, D, F)$ experiments. $(G, H)$ Total particulate $\mathrm{C}$ concentration contributed from Synechococcus and picoeukaryotes in the (E) oceanic, and (F) coastal experiments. Error bars show standard error for triplicate bottles. (I) Distributions of Synechococcus and picoeukaryote subpopulations based on forward scatter (FSC-H) and orange fluorescence (PE-H) 
increases were again highest (15-fold) for the N,P,Fe treatment, subpopulation responses differed considerably; subpopulation 3A increased fourfold while subpopulation 3B increased 23-fold.

In the coastal experiment Synechococcus and picoeukaryotes were present at more similar abundances $(17.8 \pm 0.7$ and $18.0 \pm 0.4 \times 10^{3}$ cells $\mathrm{mL}^{-1}$ ) at the start of the experiment (Figure 4). Over 3 days, Synechococcus numbers increased fivefold in the Aerosol 2 and N,P,Fe treatments $(80.3 \pm 2.1$ and $91.4 \pm 4.4 \times 10^{3}$ cells $\left.\mathrm{mL}^{-1}\right)$, and threefold in the Aerosol 1 treatment $\left(49.9 \pm 0.9 \times 10^{3}\right.$ cells $\left.\mathrm{mL}^{-1}\right)$. Picoeukaryote abundances increase for the first 2 days of incubation but then decreased during the final day for all treatments. Total picoeukaryotes also responded most strongly in the Aerosol 2 and N,P,Fe treatments, reaching $41.8 \pm 3.1 \times 10^{3}$ and $60.9 \pm 4.8 \times 10^{3}$ cells $\mathrm{mL}^{-1}$, respectively. Total picoeukaryotes in the Aerosol 1 treatment reached only $28.6 \pm 1.5 \times 10^{3}$ cells $\mathrm{mL}^{-1}$ by the last day of the experiment.

The initial cellular $\mathrm{C}$ content in the coastal experiment was $211 \pm 1 \mathrm{fg} \mathrm{C} \mathrm{cell}^{-1}$ for Synechococcus. Carbon quotas at the end of the experiment were statistically indistinguishable between control and both Aerosol treatments $\left(209 \pm 6 \mathrm{fg} \mathrm{C} \mathrm{cell}^{-1} ; p>0.05\right)$. Carbon quotas increased to $257 \pm 6 \mathrm{fg} \mathrm{C}$ cell $^{-1}$ by $\mathrm{t} 3$ in the N,P,Fe treatment, significantly higher than other treatments $(p<0.001)$. The initial picoeukaryote cellular $\mathrm{C}$ content was $953 \pm 14 \mathrm{fg} \mathrm{C}$ cell $^{-1}$ for subpopulation $3 \mathrm{~A}$ and $3177 \pm 25 \mathrm{fg} \mathrm{C}$ cell $^{-1}$ for subpopulation $3 \mathrm{~B}$. In all treatments carbon quotas decreased throughout the incubation to $885 \pm 10 \mathrm{fg} \mathrm{C}^{-1 l^{-1}}$ for subpopulation $3 \mathrm{~A}$ and $2787 \pm 83 \mathrm{fg} \mathrm{C}$ cell $^{-1}$ for subpopulation $3 \mathrm{~B}$ at $\mathrm{t} 3$.

The initial POC contributed by Synechococcus and picoeukaryotes in the coastal experiment was $47.5 \pm 0.5 \mathrm{mg} \mathrm{C} \mathrm{m}-3$ (Figure 4H). Autotrophic biomass declined slightly in the control by the end of the experiment $\left(30.5 \pm 3.7 \mathrm{mg} \mathrm{C} \mathrm{m}^{-3}\right)$. For the treatments, biomass increased for the first 2 days of incubation (maximum for N,P,Fe treatment reached $167 \pm 10.3 \mathrm{mg} \mathrm{C} \mathrm{m}^{-3}$ ) and then declined in the last day of the experiment at $t 3$, reaching final POC concentrations of $45.7 \pm 10.3 \mathrm{mg} \mathrm{C} \mathrm{m}^{-3}$, $112 \pm 48.0 \mathrm{mg} \mathrm{C} \mathrm{m}^{-3}$, and $119 \pm 21.1 \mathrm{mg} \mathrm{C} \mathrm{m}^{-3}$ for Aerosol 1 , Aerosol 2, and N,P,Fe treatments, respectively. At $\mathrm{t} 3$ subpopulation $3 \mathrm{~A}$ biomass was significantly higher in the N,P,Fe experiment $(p=0.043)$.

\section{NITRATE AND TRACE METAL DRAWDOWN}

The ambient $\mathrm{NO}_{3}^{-}$concentrations in the untreated control bottles were $0.91 \pm 0.23 \mu \mathrm{M}$ in the oceanic experiment and $0.11 \pm 0.02 \mu \mathrm{M}$ in the coastal experiment (Figure 5). Addition of aerosol to the incubation water increased the concentration of $\mathrm{NO}_{3}^{-}$above background levels. In the oceanic experiment, the $\mathrm{NO}_{3}^{-}$concentration almost doubled increasing to $1.9 \pm 0.23 \mu \mathrm{M}$ in the Aerosol 1 treatment and increased fivefold to $4.8 \pm 0.11 \mu \mathrm{M}$ in the Aerosol 2 treatment. About $2 \mu \mathrm{M} \mathrm{NO}_{3}^{-}$was drawn down by the final time point for both treatments (Figure 5). In the coastal experiment $\mathrm{NO}_{3}^{-}$was enriched to $0.63 \pm 0.07 \mu \mathrm{M}$ in the Aerosol 1 treatment and to $1.5 \pm 0.07 \mu \mathrm{M}$ in the Aerosol 2 treatment. The lower apparent enrichment in the coastal samples could be due to rapid $\mathrm{NO}_{3}^{-}$uptake during the $1 \mathrm{~h}$ it took to process the samples after aerosol additions were made. By the end of the

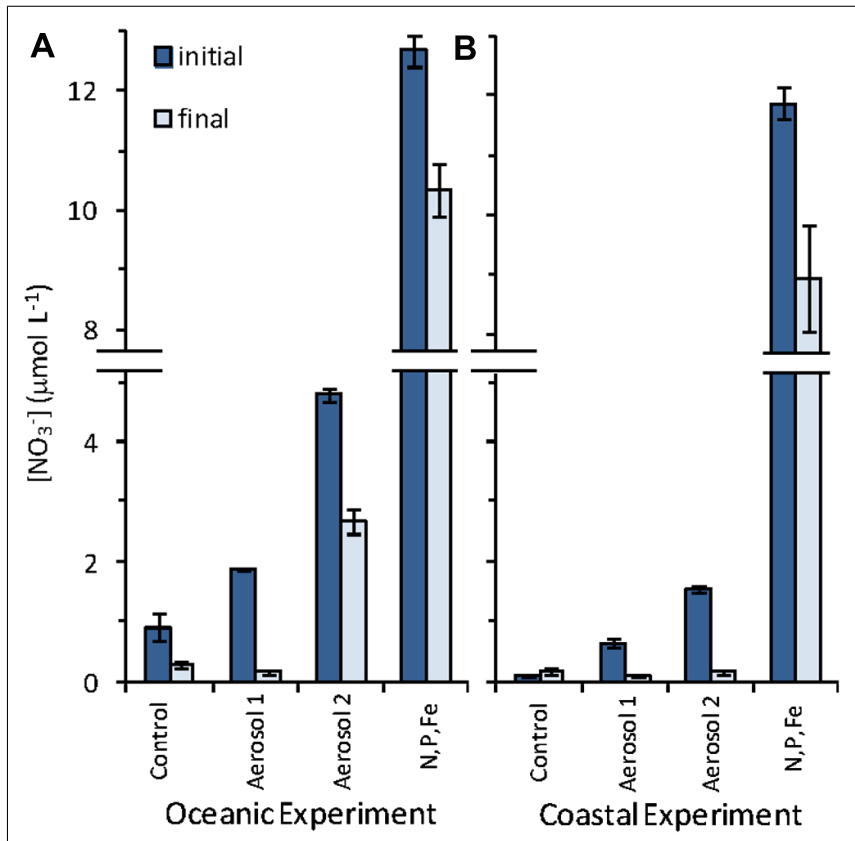

FIGURE 5 | Initial and final $\mathrm{NO}_{3}^{-}$concentrations in the (A) oceanic experiment, and (B) coastal experiment. Error bars show standard error for triplicate bottles.

coastal experiment, nearly threefold more $\mathrm{NO}_{3}^{-}$was drawn down in the Aerosol 2 treatment $(1.4 \mu \mathrm{M})$ as compared to the Aerosol 1 treatment $(0.55 \mu \mathrm{M})$.

Background trace metal concentrations in the coastal and oceanic incubation water were within the range of concentrations typically observed in the open ocean (Table 2; Sohrin and Bruland, 2011; Jickells and Burton, 1988; Sedwick et al., 2005). Aerosol 2 had higher dissolved metal content that Aerosol 1 (Table 1; Figure 2). Because the Aerosol 2 treatment induced the strongest growth response in Synechococcus in the oceanic experiment (Figure 4A) despite showing similar $\mathrm{NO}_{3}^{-}$drawdown as Aerosol 1 (Figure 5A), we measured the concentrations of seawater-soluble trace metals only in the Aerosol 2 incubation water (both open ocean and coastal) and compared that to the levels in the control and the $\mathrm{N}, \mathrm{P}, \mathrm{Fe}$ treatment (which also induced growth) with the goal of identifying which metal(s) might have been responsible for this growth response. Addition of Aerosol 2 doubled the concentrations of $\mathrm{Fe}, \mathrm{Cd}, \mathrm{Co}, \mathrm{Cu}, \mathrm{Mn}$, and $\mathrm{Ni}$ above background levels at $\mathrm{t} 0$ (Figure 6). These concentrations however, are still within the typical range for open ocean waters (Table 2). Enrichment of metals other than Fe was also evident in the N,P,Fe treatment at t0; these were likely introduced from trace amounts of these metals in the salts used to prepare the nutrient amendments.

Drawdown of dissolved trace metals during the experiment was determined by calculating the difference between $\mathrm{t} 0$ and $\mathrm{t} 3$ concentrations, and propagation of error was done to determine standard errors of the differences. Drawdown of $\mathrm{Fe}, \mathrm{Cd}, \mathrm{Co}, \mathrm{Cu}$, $\mathrm{Mn}$, and Ni was apparent in the oceanic experiment in the Aerosol 2 and N,P,Fe treatments (Figure 7). The largest variability was seen in dissolved Fe content for bottles treated with Aerosol 2 in 

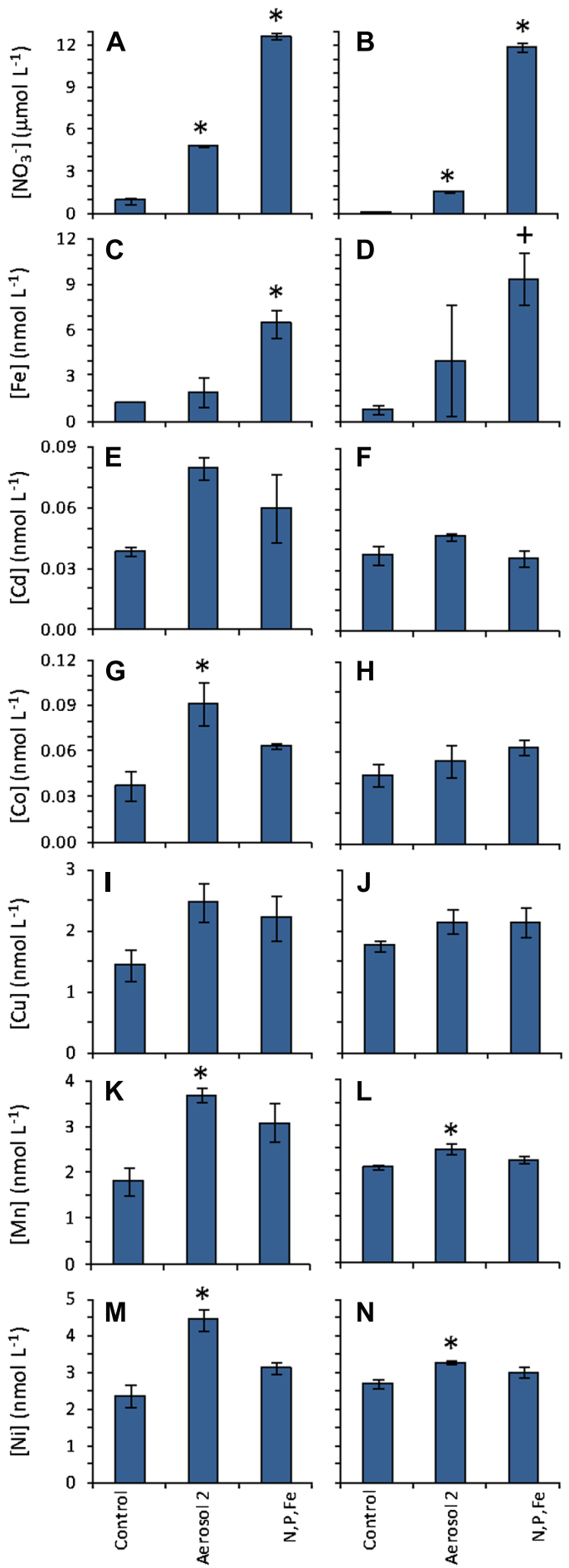

Oceanic Experiment

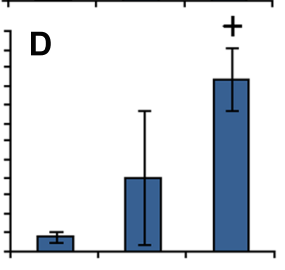

$F$
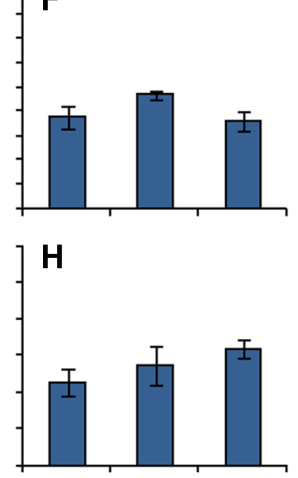

$\mathbf{J}$
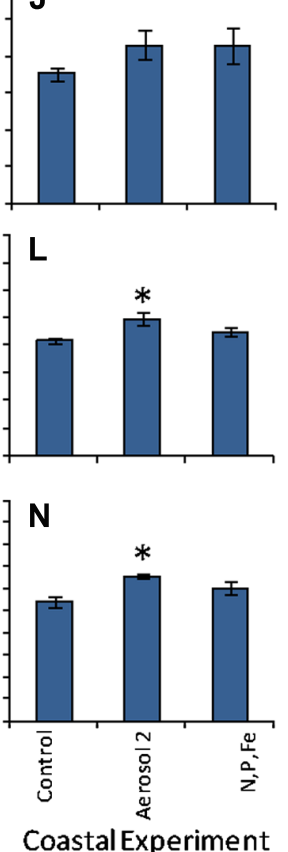

FIGURE 6 | Initial $\mathrm{NO}_{3}^{-}$and seawater-dissolved metal concentrations measured at to. Left-hand column shows values in the oceanic experiment and right-hand column shows values in the coastal experiment for $(\mathbf{A}, \mathbf{B})$ $\mathrm{NO}_{3}^{-}$; (C,D) Fe; (E,F) Cd; (G,H) Co; (I,J) Cu; (K,L) Mn; (M,N) Ni. NO 3 data is re-plotted from Figure $\mathbf{5}$ for easier comparison with the trace metal data. Error bars show standard error. Levels that were statistically different from the initial control incubation water at time zero are indicated by "* "for $p<0.05$, and " + " for $p<0.10$.

the coastal experiment (Figure 6D), and is typical of an incubation study using non-homogenized natural aerosol samples due to natural variability in the size and composition of the aerosol particles as distributed on the filter (Cahill and Wakabayashi, 1993; Mackey et al., 2010). In contrast to the oceanic experiment, there was less change over time in the concentration of dissolved metals in the coastal experiment (Figure 7), indicating little net drawdown of these metals during the incubation. In a few instances (e.g., for $\mathrm{Cu}$ and $\mathrm{Ni}$ ) final concentrations were higher than initial concentrations, and could be the result of low biological demand for these metals together with continuous release of metals from the added aerosols over time, as has been observed for aerosol $\mathrm{PO}_{4}^{3-}$ (Ridame and Guieu, 2002; Mackey et al., 2012).

\section{COPPER SPECIATION}

The initial ( $\mathrm{t} 0$ ) soluble $\mathrm{Cu}$ concentration in the oceanic experiment was $1.14 \pm 0.18 \mathrm{nM}$, and final concentrations at $\mathrm{t} 3$ were similar to initial levels in the control $(0.92 \pm 0.53)$, and enriched for both Aerosol 1 and $2(\sim 1.9 \mathrm{nM}$; Figure 8A). In the coastal experiment, the initial $\mathrm{Cu}$ concentration was $1.41 \pm 0.10 \mathrm{nM}$. The final $\mathrm{Cu}$ concentration in the control also did not change significantly by t3 $(1.43 \pm 0.19 \mathrm{nM})$, whereas enrichment occurred in Aerosol 1 $(1.60 \pm 0.18 \mathrm{nM})$ and Aerosol $2(1.88 \pm 0.18 \mathrm{nM}$; Figure 8B $)$.

Two ligand classes were identified in the experiments, a stronger ligand class (average log $K_{\mathrm{CuL}_{1}, \mathrm{Cu}^{2+}}^{\mathrm{cond}}=14.38 \pm 0.17, n=16$ ) in the higher analytical window and a weaker ligand class (average $\log K_{\mathrm{CuL}_{2}, \mathrm{Cu}^{2+}}^{\mathrm{cond}}=13.52 \pm 0.29, n=16$ ) in the lower analytical window. Both ligand classes were present in concentrations in excess of dissolved copper in all samples. Excess stronger $\mathrm{Cu}$ binding ligands $\left(\left[\mathrm{L}_{1}\right]-[\mathrm{Cu}]\right)$ increased in the Aerosol 1 addition above initial and control samples in both the oceanic and coastal experiments, while excess $\mathrm{L}_{1}$ in the Aerosol 2 treatments were similar to $\mathrm{t} 3$ control concentrations in both experiments (Figure 8). Excess $\mathrm{L}_{1}$ concentrations were similar between initial and $\mathrm{t} 3$ control bottles in the oceanic experiment, but decreased between initial and $\mathrm{t} 3$ control samples in the coastal experiment. Excess weaker $\mathrm{Cu}$-binding ligands $\left(\left[\mathrm{L}_{2}\right]-[\mathrm{Cu}]\right)$ increased in the Aerosol 2 treatment for the open ocean experiments, but were similar or lower than the control in the coastal experiment. Excess $\mathrm{L}_{2}$ concentrations were similar between $t 0$ initial, $t 3$ controls and the Aerosol 1 treatment in the open ocean experiment. In the coastal experiment, excess $\mathrm{L}_{2}$ concentrations more than doubled between the initial t 0 and the control t3, Aerosol 1 and Aerosol 2 bottles (Figure 8).

Bioavailable free, hydrated $\mathrm{Cu}^{2+}$ (hereafter referred to simply as free $\left.\mathrm{Cu}^{2+}\right)$ concentrations were low $\left(<10^{-13} \mathrm{M}\right)$ and well below toxicity thresholds for phytoplankton in all samples. Free $\mathrm{Cu}^{2+}$ levels differed markedly between the oceanic and coastal experiments (Figures 8C,D). In the oceanic experiment (Figure 8C), the initial free $\mathrm{Cu}^{2+}$ concentration and the final concentration in the control were both $\sim 4 \mathrm{fM}$. Aerosol 1 caused a slight enrichment in $\mathrm{Cu}^{2+}(\sim 5 \mathrm{fM})$. The highest free $\mathrm{Cu}^{2+}$ was observed in the Aerosol 2 treatment, where $\mathrm{Cu}^{2+}$ nearly doubled relative to initial levels $(\sim 7 \mathrm{fM})$. In contrast, the amount of free $\mathrm{Cu}^{2+}$ decreased in aerosol treatments in the coastal experiment (Figure 8D). Initial and final control levels were high $(\sim 16 \mathrm{fM})$, and decreased by half in both Aerosol 1 and $2(\sim 8 \mathrm{fM})$. 
Table 2 | Trace metal concentrations in seawater used in the oceanic and coastal incubation experiments before any nutrient or aerosol additions were made.

\begin{tabular}{|c|c|c|c|c|}
\hline Metal & $\begin{array}{l}\text { Background concentration in } \\
\text { oceanic experiment water } \\
\text { (mean } \pm \text { SE) }\end{array}$ & $\begin{array}{l}\text { Background concentration in } \\
\text { coastal experiment water } \\
\text { (mean } \pm \text { SE) }\end{array}$ & $\begin{array}{l}\text { Estimated mean concentration } \\
\text { in open ocean seawater* }\end{array}$ & $\begin{array}{l}\text { Concentration range in } \\
\text { open ocean seawater* }\end{array}$ \\
\hline $\mathrm{Cd}$ & $0.04 \pm 0.002$ & $0.04 \pm 0.005$ & 0.6 & $0.001-1.05$ \\
\hline Co & $0.04 \pm 0.010$ & $0.05 \pm 0.007$ & 0.04 & $0.003-0.3$ \\
\hline $\mathrm{Cu}$ & $1.4 \pm 0.26$ & $1.8 \pm 0.084$ & 3 & $0.4-5$ \\
\hline $\mathrm{Fe}$ & $1.3 \pm 0.047$ & $0.73 \pm 0.30$ & 0.5 & $0.03-3$ \\
\hline $\mathrm{Mn}$ & $1.8 \pm 0.31$ & $2.1 \pm 0.055$ & 0.3 & $0.06-10$ \\
\hline $\mathrm{Ni}$ & $2.4 \pm 0.30$ & $2.7 \pm 0.12$ & 8 & $2-12$ \\
\hline
\end{tabular}

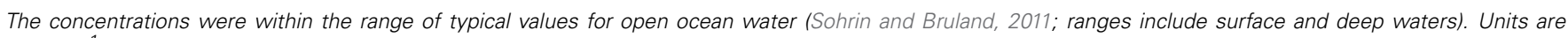
$n m o l L^{-1}$.

*Values from Sohrin and Bruland (2011).

\section{DISCUSSION}

\section{PHYTOPLANKTON COMMUNITY DYNAMICS}

The potential for atmospheric deposition to alter phytoplankton community composition via selective fertilization (Mills et al., 2004; Moore et al., 2006) and toxicity (Mann et al., 2002; Paytan et al., 2009) of different taxonomic groups has been demonstrated in various ocean waters. In the present study, we sought to evaluate the range of responses that coastal and open ocean phytoplankton communities in the Sargasso Sea would have following simulated atmospheric deposition events during the spring bloom period. Based on chl $a$ levels, the greatest increases in autotrophic biomass occurred in the N,P,Fe and the Aerosol 1 and 2 treatments. Drawdown of $\mathrm{NO}_{3}^{-}$occurred in both oceanic and coastal experiments for Aerosol 1 and Aerosol 2 (Figure 5). In contrast, $\mathrm{PO}_{4}^{3-}$ levels for Aerosol 1 and Aerosol 2 stayed the same in the coastal experiment (not shown), and actually increased in the oceanic experiment due to gradual aerosol $\mathrm{P}$ dissolution from the aerosols and DOP remineralization over the course of the experiment (Mackey et al., 2012). Chl a levels remained similar to the control at t3 following treatment with $\mathrm{N}$ alone, suggesting that autotrophic biomass at the coastal and oceanic sites required $\mathrm{Fe}$ and possibly additional metals to show maximal growth at the time of our experiments.

We compared the growth of different members of the phytoplankton community to determine differences in taxon-specific responses to atmospheric deposition and how this varied between sites, or within the same site for aerosols with different chemical compositions. At the time of our experiments the phytoplankton community at both locations was dominated by picoeukaryotes and Synechococcus. The absence of oceanic Prochlorococcus is notable, as it is typically the numerically dominant phytoplankter at the BATS site throughout much of the year. Prochlorococcus population crashes are observed annually following the maximal thermal convective mixing depth event (DuRand et al., 2001), depending on the phase and amplitude of the North Atlantic Oscillation index (NAOi) and associated regional weather (Hurrell and Deser, 2009). A particularly cold winter and strong negative anomaly of the NAOi was perhaps responsible for late winter 2010 mixing depths to exceed $400 \mathrm{~m}$ (not shown), leading to enhanced Prochlorococcus population crashes preceding our sampling.

Picoeukaryotes at both oceanic and coastal locations responded most strongly to the N,P,Fe addition (Figure 4), consistent with chl $a$ responses. Aerosol 1 and Aerosol 2 both induced moderate increases in picoeukaryote abundances in the oceanic experiment (Figures 4C,E), whereas Aerosol 2 induced more picoeukaryote growth than Aerosol 1 in the coastal experiment (Figures 4D,F). Important differences in the response of picoeukaryote subpopulations to aerosol treatments were observed in both oceanic and coastal experiments. For instance, initial subpopulation 3B abundances were lower than for subpopulation $3 \mathrm{~A}$, but the rapid growth of subpopulation $3 \mathrm{~B}$ allowed it to out-compete subpopulation 3A by the end of the oceanic experiment, such that their abundances were more comparable. This shift in the dominance of picoeukaryote subpopulations suggests that atmospheric deposition induces competition among picoeukaryotes causing changes in population distribution and abundance. Additionally, atmospheric deposition influenced the carbon dynamics within this group. Picoeukaryotes, as identified through flow cytometry, are an operationally defined group, so the increase in abundance of the larger, subpopulation $3 \mathrm{~B}$ cells in the oceanic experiment tended to increase the overall cellular POC content of picoeukaryotes relative to initial values.

Coastal Synechococcus abundance also responded differently to different treatments. Like the overall picoeukaryote community, Synechococcus abundance increased more in response to Aerosol 2 (fivefold increase) than Aerosol 1 (threefold increase), reaching levels comparable to the N,P,Fe treatment (Figure 4B). The stronger growth responses of picoeukaryotes and coastal Synechococcus to Aerosol 2 than Aerosol 1 could stem from the greater content and drawdown of $\mathrm{NO}_{3}^{-}$in the coastal experiment for Aerosol 2 (1.9 $\mu \mathrm{M}$ added and $\sim 1.5 \mu \mathrm{M}$ drawdown) compared to Aerosol 1 ( $0.6 \mu \mathrm{M}$ added and $\sim 0.5 \mu \mathrm{M}$ drawdown, Figure 5B). Treatment with $\mathrm{N}$ alone, $\mathrm{P}$ alone, or Fe alone did not stimulate growth (Figure 3B), whereas treatment with N,P,Fe induced strong growth responses, although no $\mathrm{P}$ drawdown was observed in these samples (not shown). Together these results suggest that oceanic and coastal picoeukaryotes and coastal Synechococcus 

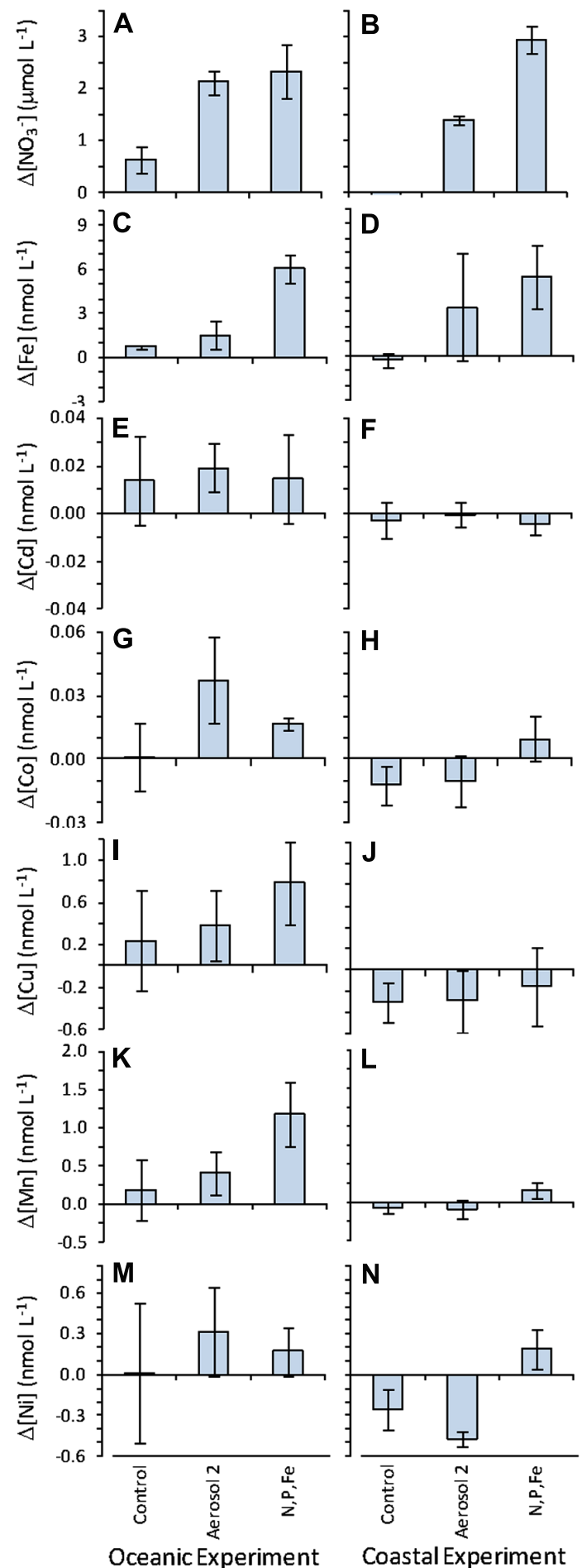

FIGURE 7 | Change in seawater-dissolved $\mathrm{NO}_{3}^{-}$and metal concentrations over $72 \mathrm{~h}$ measured as the difference between values at t0 and t3. Positive values indicate the nutrient was drawn down over the course of the experiment, and values close to zero indicate little change over the course of the experiment. Left-hand column shows values in the oceanic experiment and right-hand column shows values in the coastal experiment for (A,B) $\mathrm{NO}_{3}^{-}$; (C, $\left.\mathbf{C}\right) \mathrm{Fe}$; (E,F) Cd; (G,H) Co; (I,J) Cu; (K,L) Mn; (M,N) Ni. Error bars show standard error for the difference between mean concentrations at t0 and $\mathrm{t} 3$.
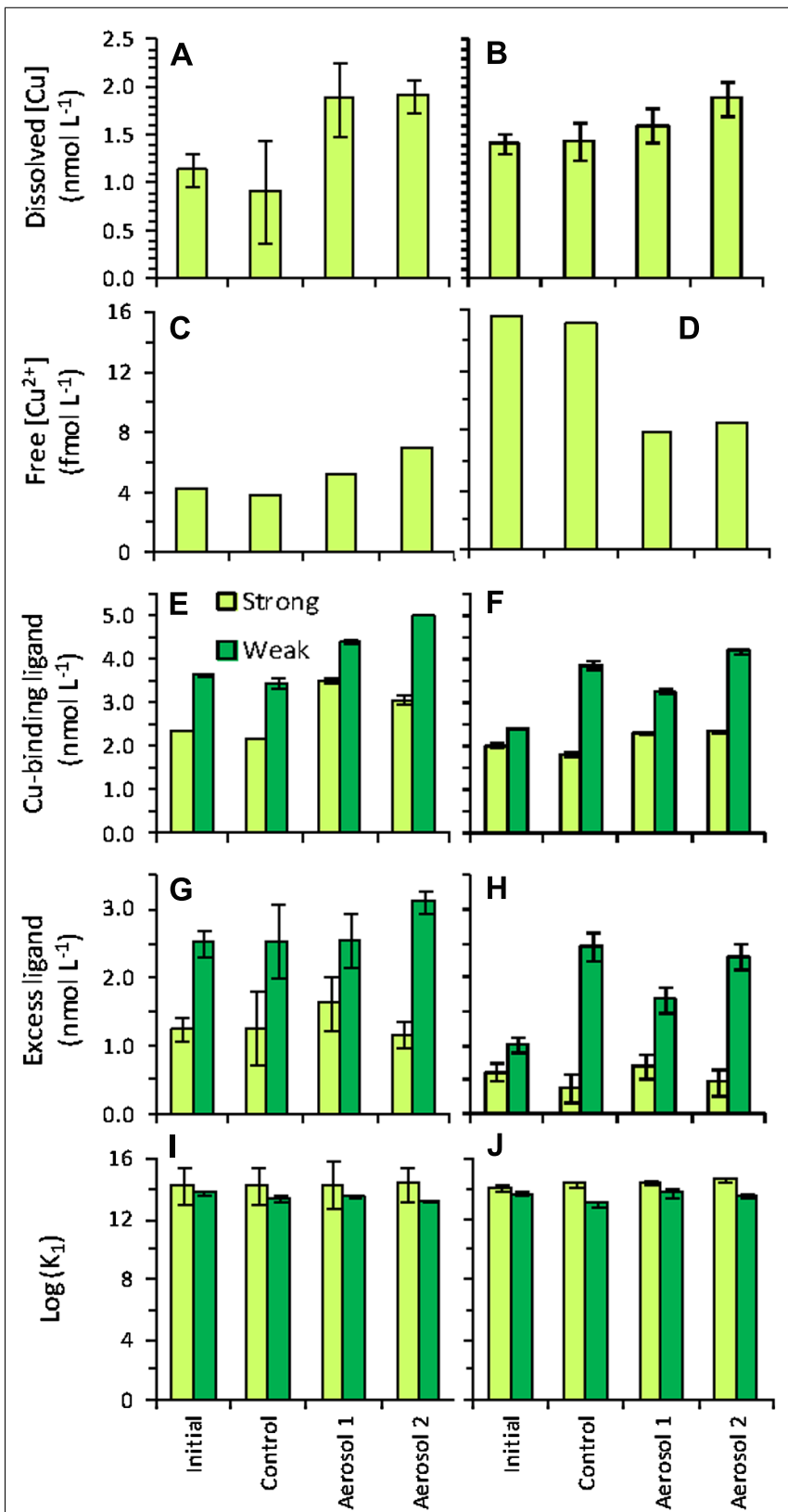

Oceanic Experiment Coastal Experiment

FIGURE 8 | Copper chemistry for initial (baseline) samples, and final (t3) samples for control, Aerosol 1, and Aerosol 2. Left-hand column shows values in the oceanic experiment and right-hand column shows values in the coastal experiment for $(\mathbf{A}, \mathbf{B})$ dissolved $\mathrm{Cu}$ concentration; (C,D) free $\mathrm{Cu}^{2+}$ concentration; (E,F) Cu-binding ligand concentration; $(\mathbf{G}, \mathbf{H})$ excess ligand concentration; (I,J) log K.

growth responded strongly to $\mathrm{N}$ and $\mathrm{Fe}$, and that atmospheric aerosols were able to relieve this limitation.

The growth response of oceanic Synechococcus to aerosol additions differed markedly from coastal Synechococcus populations (Figures 4A and B). Unlike the coastal population, oceanic Synechococcus did not respond as strongly to the inorganic nutrient addition of N,P,Fe, in keeping with the observation that oceanic 
Synechococcus respond more favorably to smaller (nanomolar) $\mathrm{NO}_{3}^{-}$additions (Glover et al., 2007). The largest oceanic Synechococcus growth response occurred when Aerosol 2 was added, which resulted in a nearly 10-fold increase in Synechococcus abundance. Unlike the coastal experiment, the drawdown of $\mathrm{NO}_{3}^{-}$was similar in the Aerosol 1, Aerosol 2, and N,P,Fe treatments in the oceanic experiment ( $\sim 2 \mu \mathrm{M}$ drawdown, Figure 5), suggesting that the stronger growth of Synechococcus was probably not due to differences in $\mathrm{NO}_{3}^{-}$uptake. Likewise, the greater growth response in Aerosol 2 was likely not due to Fe since Aerosol 1 and Aerosol 2 contributed similar dissolved Fe. Rather, our results indicate that the growth may have been due to relief from limitation by a trace metal micronutrient, since Aerosol 2 had a higher compliment of most dissolved metals than Aerosol 1 (Table 1; Figure 2).

To determine which micronutrients in Aerosol 2 might have contributed to the strong growth response of Synechococcus in the oceanic experiment, we compared the initial levels and calculated the drawdown of several biologically important metals to see which had been drawn down as the Synechococcus bloomed (Figure 7). In the oceanic experiment, drawdown of Fe, Cd, Co, $\mathrm{Cu}, \mathrm{Mn}$, and $\mathrm{Ni}$ all occurred following addition of Aerosol 2. Additionally, initial levels of $\mathrm{Co}, \mathrm{Mn}$, and Ni were significantly higher in the aerosol 2 treatment compared to the control (Figure 6), whereas they were not significantly higher than the control in the $\mathrm{N}, \mathrm{P}, \mathrm{Fe}$ treatment. This suggests that aerosol-derived Co, Mn, or Ni may have contributed to the strong Synechococcus growth response to Aerosol 2.

Unlike eukaryotic phytoplankton, Synechococcus has an absolute requirement for Co that cannot be satisfied by other metals. Eukaryotic phytoplankton, including diatoms and coccolithophores, are able to substitute $\mathrm{Zn}$ for Co, thereby maintaining growth even when Co levels are vanishingly low (Sunda and Huntsman, 1995a; Saito and Goepfert, 2008). In contrast, Synechococcus cells cannot substitute $\mathrm{Zn}$ for $\mathrm{Co}$, and their populations have been shown to correlate with dissolved Co concentrations in the Sargasso Sea (Saito and Moffett, 2001) and the Costa Rica Upwelling Dome in the Equatorial Pacific Ocean (Saito et al., 2005). Moreover, concentrations of Co-binding ligands also co-vary with Synechococcus cell abundances at these locations, leaving open the possibility that Synechococcus produces these organic chelating compounds to help acquire Co where Co concentrations are in the low picomolar range. The high affinity of Synechococcus for Co is one of many adaptations that could contribute to high Synechococcus abundance during the spring bloom in the Sargasso Sea. The preference of Synechococcus to utilize $\mathrm{NO}_{3}^{-}$as a $\mathrm{N}$ source may also promote Synechococcus growth over that of Prochlorococcus, which tends to dominate this region during the stratified season when $\mathrm{NO}_{3}^{-}$levels are very low (Moore et al., 2008; Martiny et al., 2009).

Relief from Co limitation is a possible explanation for the strong Synechococcus growth response observed in response to the Aerosol 2 addition. However, this explanation does not rule out the possibility that Synechococcus were driven to Co limitation during the experiment by the high levels of $\mathrm{NO}_{3}^{-}$in Aerosol 2, or that they benefited from other metals that were introduced by Aerosol 2. Additionally, it is possible that other phytoplankton and bacteria may have contributed to the drawdown of Co we observed in the Aerosol 2 treatment. The cellular Co quota for cultured Synechococcus bacillaris ranges from 0.08 to $1.43 \mu \mathrm{molCo} \mathrm{molC}^{-1}$, similar to the Co content of particulate material in the Sargasso Sea in which picoplankton dominate $\left(\sim 1.5 \mu\right.$ molCo $\mathrm{molC}^{-1}$; Sherrell and Boyle, 1992). In the oceanic experiment, Synechococcus POC increased $\sim 70 \mathrm{mgC} \mathrm{m}^{-3}$ in response to the Aerosol 2 treatment (Figure 4G). Taking the higher cellular Co quota estimate of $1.5 \mu$ molCo molC $^{-1}$, this increase in Synechococcus POC would have only required $\sim 9$ pM Co uptake, suggesting that picoeukaryotes and other microbes may have also contributed to the $40 \pm 20$ pM Co drawdown we observed.

Other biologically relevant metals, such as $\mathrm{Mn}$ and $\mathrm{Ni}$, were also drawn down over the course of the experiment, suggesting that they too fueled the growth of the phytoplankton community. $\mathrm{Mn}$ is an important plant micronutrient, and is a central component of the oxygen evolving complex of photosystem II in all photosynthetic organisms, including phytoplankton (Falkowski and Raven, 2007). Mn is also a cofactor in the superoxide dismutase (SOD) enzyme of diatoms that protects cells from oxidative stress (Wolfe-Simon et al., 2006). Similarly, Ni is a cofactor in some (cyano)bacterial SOD enzymes (Palenik et al., 2003), as well as a cofactor for the urease enzymes of many marine phytoplankton (Price and Morel, 1991; Palinska et al., 2000). The sharp drawdown of these metals during the oceanic incubation experiment suggests that aerosol-associated $\mathrm{Mn}$ and $\mathrm{Ni}$ enrichment has the potential to supply phytoplankton with these vital micronutrients in the open ocean.

In addition to requiring metals for nutritional purposes, the higher resistance to $\mathrm{Cu}$ toxicity in Synechococcus compared to Prochlorococcus has also been proposed to shape phytoplankton community structure in the Sargasso Sea, particularly during the summer-stratified period (Mann et al., 2002). The bioavailability of dissolved $\mathrm{Cu}$ has been shown to be a function of free $\mathrm{Cu}^{2+}$ concentrations, and not total dissolved $\mathrm{Cu}$ concentrations (Sunda and Guillard, 1975). As dissolved $\mathrm{Cu}$ is typically complexed by strong organic ligands in seawater, $\mathrm{Cu}$ bioavailability is dependent upon ambient $\mathrm{Cu}$ speciation. In our oceanic experiment, $\mathrm{Cu}^{2+}$ concentrations were similar between the initial and $\mathrm{t} 3$ control bottles, increased slightly in the Aerosol 1 treatment, and nearly doubled over control concentrations in the Aerosol 2 treatment. In contrast, in the coastal experiment, $\mathrm{Cu}^{2+}$ concentrations in the initial and $\mathrm{t} 3$ control were roughly fourfold higher than observed in the initial and control bottles of the oceanic experiment, and decreased by nearly half in both the Aerosol 1 and Aerosol 2 treatments.

$\mathrm{Cu}^{2+}$ concentrations in the oceanic and coastal experiments were well below toxicity thresholds for marine phytoplankton, including Synechococcus species (toxicity threshold $\sim 10^{-11} \mathrm{M}$; Brand et al., 1986) in all samples and treatments. Thus, Cu toxicity is not likely to have had an effect on phytoplankton growth in these experiments. This is consistent with previous $\mathrm{Cu}$ addition experiments in the Sargasso Sea showing no decrease in the growth of Synechococcus following $2 \mathrm{nM} \mathrm{Cu}$ additions (Mann et al., 2002).

The changes in $\mathrm{Cu}^{2+}$ concentrations in the oceanic and coastal experiments reflect the changes in total dissolved $\mathrm{Cu}$ and strong $\mathrm{Cu}$-binding ligands measured in the experiments. In the absence of a change in $\mathrm{L}_{1}$ concentrations, the increase in dissolved $\mathrm{Cu}$ 
measured from the aerosol treatments would have increased $\mathrm{Cu}^{2+}$ concentrations in both the coastal and oceanic experiments. However, only in the Aerosol 2 treatment of coastal waters, where dissolved $\mathrm{Cu}$ concentrations $(1.88 \mathrm{nM})$ would have exceeded the $\mathrm{L}_{1}$ concentrations measured in the $\mathrm{t} 3$ control $(1.82 \mathrm{nM})$, would $\mathrm{Cu}^{2+}$ concentrations have increased dramatically and approached toxicity thresholds for Synechococcus in the absence of Cu-binding ligand production. Synechococcus have been shown to produce $\mathrm{Cu}$ binding ligands under $\mathrm{Cu}$ toxicity stress in the laboratory (Moffett and Brand, 1996), but there is no indication of Cu toxicity in any of the treatments and Synechococcus growth was much higher in the Aerosol 2 treatment than Aerosol 1. It is not obvious, then, why excess $\mathrm{Cu}$-binding ligands in both experiments were highest in the Aerosol 1 treatments, and similar between initial, $\mathrm{t} 3$ control, and $\mathrm{t} 3$ Aerosol 2 treatments.

It is also notable that initial $\mathrm{Cu}$-binding ligand concentrations were in greater excess of dissolved $\mathrm{Cu}$ in the oceanic waters than in the coastal waters. This is counterintuitive if $\mathrm{Cu}$-binding ligands are primarily produced by cyanobacteria to alleviate $\mathrm{Cu}$ toxicity, as $\mathrm{Cu}^{2+}$ concentrations were well below toxicity thresholds throughout both of these experiments, even after aerosol-associated $\mathrm{Cu}$ additions. The sources and function of $\mathrm{Cu}$-binding ligands, particularly in oceanic waters, merits further attention, as the conventional wisdom linking $\mathrm{Cu}$ toxicity with ligand production does not fit well here. Recent studies have highlighted the role of $\mathrm{Cu}$ as a micronutrient in the ocean, limiting large diatom growth under low Fe conditions (Peers et al., 2005; Peers and Price, 2006). However, experiments in this study were dominated by picoeukaryotes and cyanobacteria under relatively Fe replete conditions, hence regulation of nutritional $\mathrm{Cu}$ uptake may be more complicated than previously believed.

Prochlorococcus was not abundant in our incubation water, so we were unable to directly assess how aerosol-derived $\mathrm{Cu}$ would affect this population. The results of Mann et al. (2002) show that $\mathrm{Cu}$ toxicity to Prochlorococcus in this region can occur following $2 \mathrm{nM}$ or less $\mathrm{Cu}$ enrichment. Our results show that following moderate amounts of aerosol enrichment, $\mathrm{Cu}^{2+}$ levels remained well below the toxicity threshold for Prochlorococcus during the spring. However, the summer-stratified period generally has more large atmospheric deposition events, and Cu-binding ligand concentrations are $\sim$ twofold lower than during winter mixing (Moffett, 1995; Mann et al., 2002). This leaves open the possibility that aerosol-Cu enrichment could potentially curb Prochlorococcus growth in the summer-stratified period, but this would likely be limited to exceptionally large deposition events of aerosols with high fractions of soluble $\mathrm{Cu}$.

\section{THE IMPACTS OF ATMOSPHERIC METALS IN THE SURFACE OCEAN}

During the spring in the Sargasso Sea, nutrients introduced during winter mixing are trapped within the sunlit layer as the surface ocean stratifies, providing conditions necessary for the spring bloom to occur. $\mathrm{NO}_{3}^{-}$availability is high in the spring relative to the rest of the year, and has been shown to drive the system toward Fe limitation (Moore et al., 2006). Moore et al. (2006) show that the supply of Fe from atmospheric deposition could influence the initiation, duration, and magnitude of the spring bloom by regulating phytoplankton $\mathrm{NO}_{3}^{-}$uptake, thereby stimulating new primary production. The results of the incubation experiments in this study support the hypothesis of Moore et al. (2006) regarding the importance of atmospheric deposition as a source of Fe that regulates the spring bloom, as the greatest increases in photosynthetic biomass were observed in treatments where Fe (and N) were available.

In addition to supplying $\mathrm{Fe}$, our results also suggest an additional role for atmospheric deposition during the spring bloom. Atmospheric deposition can influence phytoplankton community composition during the spring bloom by providing other trace metal micronutrients, such as Co, that could limit growth as the bloom progresses. These findings are in agreement with those of Shelley et al. (2010), who observed that the nutrient-like profile for dissolved Co displayed a surface maximum following a period of strong aeolian deposition in the Sargasso Sea. The results presented here suggest that aerosol-derived Co is bioavailable and can support the growth of phytoplankton. Our results also show that in addition to Fe and Co, aerosols provide many biologically important trace metals needed for phytoplankton growth (Figure 6), and that these nutrients get consumed as cells grow (Figure 7). The selective enhancement of Synechococcus abundance in the oceanic experiment demonstrates the potential for these aerosol-derived metals to cause shifts in community composition by relieving the nutrient limitation of certain taxa and altering competition among different subpopulations.

The influence and fate of atmospheric metals may differ spatially in the Sargasso Sea. In the oceanic experiment, metals were consumed rapidly as phytoplankton grew. In contrast, little drawdown occurred following aerosol additions in the coastal experiment, suggesting that coastal phytoplankton assemblages may have been less stressed for these metals. This difference between sites may stem from a greater input of metals to coastal waters from terrigenous sources (e.g., runoff, groundwater) and resuspension of shelf sediments, compared to the open ocean that has fewer sources of trace metals. Alternately, the results could point toward a higher degree of $\mathrm{NO}_{3}^{-}$limitation in the coastal population, which may have precluded greater uptake of trace metal. Indeed, all of the $\mathrm{NO}_{3}^{-}$contributed by Aerosol 2 was consumed by the end of the coastal experiment, whereas $>2 \mu \mathrm{M}$ residual $\mathrm{NO}_{3}^{-}$ persisted in the oceanic experiment (Figure 5). If coastal phytoplankton became $\mathrm{NO}_{3}^{-}$limited during the experiment, this may have precluded efficient uptake of aerosol-derived trace metals.

The effect of atmospheric metal deposition on bloom development depends on the nutrient status of the resident phytoplankton assemblage, the aerosol depositional flux to the ocean's surface, and the chemical composition of the aerosol. The Sargasso Sea receives a substantial input of Sahara dust during the summer months, whereas in the winter aerosols from North America predominate (Prospero et al., 1996). In this study both Aerosol samples contained a mixture of material from Sahara and North American sources (not shown); however, Aerosol 2 had more anthropogenic material than Aerosol 1 and caused a stronger growth response in the oceanic phytoplankton community that was commensurate with metal drawdown. The flux of soluble metal (i.e., the fraction that is likely available to phytoplankton) depends strongly on the relative proportions of anthropogenic versus mineral particles a region receives. Anthropogenic aerosols can be $>10$-fold 
enriched relative to average crustal abundances in metals such as $\mathrm{Ni}, \mathrm{Cu}, \mathrm{Zn}, \mathrm{Pb}$, and Cd (Chen et al., 2008; Chase et al., 2011). More variability exists in the total Fe content in atmospheric deposition with respect to anthropogenic and mineral sources; however, anthropogenic aerosols tend to have much higher fractional metal solubility compared to mineral aerosol (i.e., a greater proportion of the total Fe is water soluble, Sholkovitz et al., 2012). Similar solubility trends have been observed for $\mathrm{Cu}$ in the North Atlantic, where the fractional solubility of $\mathrm{Cu}$ in anthropogenic sources ranges from 10 to $100 \%$, while $\mathrm{Cu}$ in mineral aerosol from the Sahara desert is less soluble (1-7\%; Sholkovitz et al., 2010). Accordingly, the amount of soluble, and presumably bioavailable, metals arriving at a location may be strongly influenced by even small inputs of anthropogenic aerosol.

Since the spring bloom is a transitional time for air masses reaching the Sargasso Sea (Prospero et al., 1996), the amount of bioavailable metals delivered via atmospheric deposition would depend strongly on the relative proportion of anthropogenic aerosols in a given deposition event. In this study, Aerosol 2 was enriched in $\mathrm{V}$ relative to $\mathrm{Al}$, a property that indicates greater anthropogenic input. The higher soluble metal content and greater fertilization potential of Aerosol 2 (Figures 6 and 4), may therefore be linked to an anthropogenic source. Our results suggest that the effect of atmospheric deposition during the spring bloom therefore depends not only on the amount of deposition, but the specific source and chemical composition of the aerosol deposited. The greater input of anthropogenic aerosols in the late winter/early spring as the bloom develops could be important in determining the magnitude of $\mathrm{NO}_{3}^{-}$drawdown, as has been proposed for aerosol Fe (Moore et al., 2006), as well as in shaping phytoplankton community composition, as observed for Aerosol 2 in this study. Coupled ecosystem-biogeochemical models that include atmospheric deposition should include this distinction where possible to explore its effect on productivity.

\section{CONCLUSION}

In this study we sought to understand the effect of atmospheric metal deposition on oceanic and coastal Sargasso Sea phytoplankton communities. This study shows that aerosol deposition contributes biologically important constituents in addition to $\mathrm{Fe}$

\section{REFERENCES}

Arimoto, R., Duce, R. A., Ray, B. J., Ellis, W. G., Cullen, J. D., and Merrill, J. T. (1995). Trace elements in the atmosphere over the North Atlantic. J. Geophys. Res. 100, 1199-1213.

Bange, H., Rixen, T., Johansen, A., Siefert, R., Ramesh, R., Ittekkot, V., et al. (2000). A revised nitrogen budget for the Arabian Sea. Glob. Biogeochem. Cycles 14, 1283-1297.

Bergametti, G., Remoudaki, E., Losno, R., Steiner, E., Chatenet, B., and BuatMenard, P. (1992). Source, transport, and deposition of atmospheric phosphorus over the northwestern Mediterranean. J. Atmos. Chem. 14, 501-513.
Bertilsson, S., Berglund, O., Karl, D. M., and Chisholm, S. W. (2003). Elemental composition of marine Prochlorococcus, and Synechococcus: implications for the ecological stoichiometry of the sea. Limnol. Oceanogr. 48, 1721-1731.

Brand, L. E., Sunda, W. G., and Guillard, R. R. L. (1986). Reduction of marine phytoplankton reproduction rates by copper and cadmium. J. Exp. Mar. Biol. Ecol. 96, 225-250.

Bruland, K. W., Donat, J. R., and Hutchins, D. A. (1991). Interactive influences of bioactive trace metals on biological production in oceanic waters. Limnol. Oceanogr. 36, 15551577.

and $\mathrm{N}$ to seawater, and that these bioavailable metals get consumed over time scales commensurate with cell growth. In particular, aerosol-derived micronutrients like Co, for which certain taxa have absolute requirements (Sunda and Huntsman, 1995a), may favor the growth of certain subpopulations and alter phytoplankton community composition. In contrast, during the spring season when these experiments were conducted, $\mathrm{Cu}$ toxicity did not appear to be an important factor influencing phytoplankton community composition.

The solubility of atmospheric metals is an important factor affecting metal bioavailability, and the relative proportions of anthropogenic and mineral sources in atmospheric deposition has the potential to influence phytoplankton growth and community composition in a given region. Accordingly, different types of aerosol can elicit very different growth responses from phytoplankton communities. These responses can differ between distinct populations despite their relatively close geographic proximity, and can reflect different antecedent conditions to which the cells were exposed with respect to metal availability.

\section{ACKNOWLEDGMENTS}

We thank R. Johnson and E. Reistetter for logistical assistance at sea, and A. Peters for collection of the aerosol samples. Operation of the Marine-Atmospheric Sampling Facility at Tudor Hill, Bermuda is funded by NSF award \#082571. This manuscript benefited from thoughtful review comments from M. M. Mills, S. Sanudo-Wilhelmy, and M. A. Saito. This research was supported by NSF-OCE grant 0850467 to Adina Paytan, funds from the Steel Industry Foundation for the advancement of Environmental Protection Technology and from Grant-in-Aid for Scientific Research, the Ministry of Education, Science, Sports, and Culture of Japan to Yoshiki Sohrin, and NSF-OCE grant 0752366 to Michael W. Lomas and Kristen N. Buck was supported by institutional funding from the Walwyn Hughes Fund for Innovation and the Ray Moore Endowment Fund at the Bermuda Institute of Ocean Sciences (BIOS). This material is based upon work supported in part by a National Science Foundation Postdoctoral Research Fellowship in Biology under Grant No. NSF 1103575 to Katherine R. M. Mackey. This is BIOS contribution number 2020.

Bruland, K. W., Rue, E. L., and Smith, G. J. (2001). Iron and macronutrients in California coastal upwelling regimes: implications for diatom blooms, Limnol. Oceanogr. 46, 1661-1674.

Buck, C. S., Landing, W. M., Resing, J. A., and Lebon, G. T. (2006). Aerosol iron and aluminum solubility in the northwest Pacific Ocean: results from the 2002 IOC cruise. Geochem. Geophys. Geosyst. 7, Q04M07. doi: 10.1029/2005GC000977

Buck, K. N., and Bruland, K. W. (2005). Copper speciation in San Francisco Bay: a novel approach using multiple analytical windows. Mar. Chem. 96, 185-198.

Buck, K. N., Selph, K. E., and Barbeau, K. A. (2010). Iron-binding ligand production and copper speciation in an incubation experiment of Antarctic Peninsula shelf waters from the Bransfield Strait, Southern Ocean. Mar. Chem. 122, 148-159.

Cahill, T. A., and Wakabayashi, P. (1993). "Compositional analysis of size-segregated aerosol samples." in Measurement Challenges in Atmospheric Chemistry, ed L. Newman (Washington, DC: ACS Publications), 211-228.

Casey, J. R., Aucan, J. P., Goldberg, S. R., and Lomas, M. W. (2012). Changes in the partitioning of carbon amongst autotrophic pico- and nanoplankton groups in response to changes in the North Atlantic Oscillation. Deep Sea 
Res. Part II Top. Stud. Oceanogr. (in review).

Chase, Z., Paytan, A., Beck, A., Biller, D., Bruland, K., Measures, C., et al. (2011). Evaluating the impact of atmospheric deposition on dissolved trace-metals in the Gulf of Aqaba, Red Sea. Mar. Chem. 126, 256-268.

Chen, L., and Duce, R. A. (1983). The sources of sulfate, vanadium and mineral matter in aerosol particles over Bermuda. Atmos. Environ. 17, 2055-2064.

Chen, Y., Paytan, A., Chase, Z., Measures, C., Beck, A. J., SañudoWilhelmy, S. A., et al. (2008). Sources and fluxes of atmospheric trace elements to the Gulf of Aqaba, Red Sea. J. Geophys. Res. 113, D05306.

Duce, R. A., LaRoche, J., Altieri, K., Arrigo, K. R., Baker, A. R., Capone, D. G., et al. (2008). Impacts of atmospheric anthropogenic nitrogen on the open ocean. Science 320, 893-897.

Duce, R. A., Liss, P. S., Merrill, J. T., Atlas, E. L., Buat-Menard, P., Hicks, B. B., et al. (1991). The atmospheric input of trace species to the world ocean. Glob. Biogeochem. Cycles 5, 193-259.

Duce, R. A., and Tindale, N. W. (1991). Atmospheric transport of iron and its deposition in the ocean. Limnol. Oceanogr. 36, 1715-1726.

DuRand, M., Olson, R., and Chisholm, S. W. (2001). Phytoplankton population dynamics at the Bermuda Atlantic Time-series station in the Sargasso Sea. Deep Sea Res. Part II Top. Stud. Oceanogr. 48, 1983-2003.

Falkowski, P. G., and Raven, J. A. (2007) Aquatic Photosynthesis, 2nd Edn, Princeton: Princeton University Press.

Glover, H. E., Garside, C., and Trees, C. C. (2007). Physiological responses of Sargasso Sea picoplankton to nanomolar nitrate perturbations. $J$. Plankton Res. 29, 263-274.

Guo, C., Yu, J., Ho, T.-Y., Chen, B., Wang, L., Song, S., et al. (2011). Dynamics of phytoplankton community structure in the South China Sea in response to the East Asian aerosol input. Biogeosci. Discuss. 8, 6637-6680.

Herut, B., Krom, M. D., Pan, G., and Mortimer, R. (1999). Atmospheric input of nitrogen, and phosphorus to the southeast Mediterranean: sources, fluxes, and possible impact. Limnol. Oceanogr. 44, 1683-1692.

Hurrell, J. W., and Deser, C. (2009). North Atlantic climate variability: the role of the North Atlantic Oscillation. J. Mar. Syst. 78, 28-41.

JGOFS. (1994). "Measurement of chlorophyll $a$ and phaeopigments by fluorometric analysis," in Protocols for the Joint Global Ocean Flux Study (JGOFS) Core Measurements, IOC Manuals and Guides No. 29 (Paris: UNESCO).

Jickells, T. D., An, Z. S., Andersen, K. K., Baker, A. R., Bergametti, G., Brooks, N., et al. (2005). Global iron connections between aerosol, ocean biogeochemistry and climate. Science 308, 67-71.

Jickells, T. D., and Burton, J. D. (1988). Cobalt, copper, manganese, and nickel in the Sargasso Sea. Mar. Chem. 23, 131-144.

Mackey, K. R. M., Labiosa, R. G., Calhoun, M., Street, J. H., and Paytan, A. (2007). Phosphorus availability, phytoplankton community dynamics, and taxon-specific phosphorus status in the Gulf of Aqaba, Red Sea. Limnol. Oceanogr. 52, 875-885.

Mackey, R. K. M., Roberts, K. Lomas, M. W., Post, A. F., Saito, M., and Paytan, A. (2012). Variable solubility and ecological impact of atmospheric phosphorus deposition. Environ. Sci. Technol. http://dx.doi.org/10.1021/es3007996

Mackey, K. R. M., van Djiken G., Mazloom, S., Erhardt, A. M., Ryan, J., Arrigo, K., et al. (2010). Influence of atmospheric nutrients on primary productivity in a coastal upwelling region. Glob. Biogeochem. Cycles 24, GB4027. doi: 10.1029/2009GB003737

Mahowald, N. M., Baker, A. R., Bergametti, G., Brooks, N., Duce, R. A. Jickells, T. D., etal. (2005). The atmospheric global aerosol cycle and iron inputs to the ocean. Glob. Biogeochem. Cycles 19, GB4025. doi: 10.1029/2004GB002402

Mann, E. L., Ahlgren, N., Moffett, J. W., and Chisholm, S. W. (2002). Copper toxicity and cyanobacteria ecology in the Sargasso Sea. Limnol. Oceanogr. 47, 976-988.

Martiny, A. C., Kathuria, S., and Berube, P. M. (2009). Widespread metabolic potential for nitrite and nitrate assimilation among Prochlorococcus ecotypes. Proc. Natl. Acad. Sci. U.S.A. 106, 10787-10792.

Michaels, A. F., Siegel, D. A., Johnson, R. J., Knap, A. H., and Galloway, J. N. (1993). Episodic inputs of atmospheric nitrogen to the Sargasso Sea: contributions to new production and phytoplankton blooms. Glob. Biogeochem. Cycles 7, 339-351.

Mills, M. M., Ridame, C., Davey, M., and La Roche, J. (2004). Iron, and phosphorus co-limit nitrogen fixation in the eastern tropical North Atlantic. Nature 429, 292-294.
Moffett, J. W. (1995). Temporal and spatial variability of copper complexation by strong chelators in the Sargasso Sea. Deep Sea Res. Part I Oceanogr. Res. Pap. 42, 1273-1295.

Moffett, J. W., and Brand, L. E. (1996). Production of strong, extracellular $\mathrm{Cu}$ chelators by marine cyanobacteria in response to $\mathrm{Cu}$ stress. Limnol. Oceanogr. 41, 388-395.

Moffett, J. W., and Dupont, C. (2007). $\mathrm{Cu}$ complexation by organic ligand in the sub-arctic NW Pacific and Bering Sea. Deep Sea Res. Part I Oceanogr. Res. Pap. 54, 586-595.

Moore, C. M., Mills, M. M., Langlois, R., Milne, A., Achterberg, E. P., LaRoche, J., et al. (2008). Relative influence of nitrogen and phosphorus availability on phytoplankton physiology and productivity in the oligotrophic sub-tropical North Atlantic Ocean. Limnol. Oceanogr. 53, 291-305.

Moore, C. M., Mills, M. M., Milne, A., Langlois, R., Achterberg, E. P. Lochte, K., et al. (2006). Iron limits primary productivity during spring bloom development in the central North Atlantic. Glob. Change Biol. 12, 626-634.

Paerl, H. W. (1997). Coastal eutrophication and harmful algal blooms: importance of atmospheric deposition and groundwater as "new" nitrogen and other nutrients. Limnol. Oceanogr. 42, 1154-1165.

Palenik, B., Brahamsha, B., Larimer, F. W., Land, M., Hauser, L., Chain, P., et al. (2003). The genome of a motile marine Synechococcus. Nature 424, 1037-1042.

Palinska, K. A., Jahns, T., Rippka, R. and Tandeau de Marsac, N. (2000). Prochlorococcus marinus strain PCC 9511, a picoplanktonic cyanobacterium, synthesizes the smallest urease. Microbiology 146, 3099-3107.

Paytan, A., Mackey, K. R. M., Chen, Y., Lima, I. D., Doney, S. C., Mahowald, N., et al. (2009). Toxicity of atmospheric aerosols on marine phytoplankton. Proc. Natl. Acad. Sci. U.S.A. 106, 4601-4605.

Peers, G., and Price, N. M. (2006). Copper-containing plastocyanin used for electron transport by an oceanic diatom. Nature 441, 341-344.

Peers, G., Quesnel, S.-A., and Price, N. M. (2005). Copper requirements for iron acquisition and growth of coastal and oceanic diatoms. Limnol. Oceanogr. 50, 1149-1158.

Price, N. M., and Morel, F. M. M. (1991). Colimitation of phytoplankton growth by nickel and nitrogen. Limnol. Oceanogr. 36, 1071-1077.
Prospero, J. M., Barrett, K., Church, T., Dentener, F., Duce, R. A., Galloway, J. N., et al. (1996). Atmospheric deposition of nutrients to the North Atlantic basin. Biogeochemistry 35, 27-73.

Prospero, J. M., and Savoie, D. L. (1989). Effect of continental sources on nitrate concentrations over the Pacific Ocean. Nature 339, 687-689.

Redfield, A. C., Ketchum, B. H., and Richards, F. A. (1963). "The influence of organisms on the composition of seawater," in The Sea, Vol. 2, ed. M. N. Hill (New York: Wiley Interscience), 26-77.

Ridame, C., and Guieu, C. (2002). Saharan input of phosphate to the oligotrophic water of the open western Mediterranean Sea. Limnol. Oceanogr. 47, 856-869.

Ružic, I. (1982). Theoretical aspects of the direct titration of natural waters and its information yield for trace metal speciation. Anal. Chim. Acta 140, 99-113.

Saito, M. A., and Goepfert, T. J. (2008). Zinc-cobalt colimitation of Phaeocystis Antarctica. Limnol. Oceanogr. 53, 266-275.

Saito, M. A., and Moffett, J. W. (2001). Complexation of cobalt by natural organic ligands in the Sargasso Sea as determined by a new high-sensitivity electrochemical cobalt speciation method suitable for open ocean work. Mar. Chem. 75, 49-68.

Saito, M. A., Moffett, J. W. S., Chisholm, W., and Waterbury, J. B. (2002). Cobalt limitation and uptake in Prochlorococcus. Limnol. Oceanogr. 47, 1629-1636.

Saito, M. A., Rocap, G., and Moffett, J. W. (2005). Production of cobalt binding ligands in a Synechococcus feature at the Costa Rica Upwelling Dome. Limnol. Oceanogr. 50, 279-290.

Scatchard, G. (1949). The attractions of proteins for small molecules and ions. Ann. N. Y. Acad. Sci. 51, 660-672.

Sedwick, P. N., Church, T. M., Bowie, A. R., Marsay, C. M., Ussher, S. J., Achilles, K. M., et al. (2005). Iron in the Sargasso Sea (Bermuda Atlantic Time-series Study region) during summer: Eolian imprint, spatiotemporal variability, and ecological implications. Glob. Biogeochem. Cycles 19, GB4006.

Sedwick, P. N., Sholkovitz, E. R., and Church, T. M. (2007). Impact of anthropogenic combustion emissions on the fractional solubility of aerosol iron: Evidence from the Sargasso Sea. Geochem. Geophys. Geosyst. 8, Q10Q06, doi: 10.1029/ 2007GC001586 
Shelley, R. U., Zachhuber, B., Sedwick, P. N., Worsfold, P. J., and Lohan, M. C. (2010). Determination of total dissolved cobalt in UV-irradiated seawater using flow injection with chemiluminescence detection. Limnol. Oceanogr. Methods 8, 352-362.

Sherrell, R. M., and Boyle, E. A. (1992). The trace metal composition of suspended particles in the oceanic water column near Bermuda. Earth Planet. Sci. Lett. 111 , 155-174.

Sholkovitz, E. R., and Sedwick, P. N. (2006). Open-ocean deployment of a buoy-mounted aerosol sampler on the Bermuda Testbed Mooring: aerosol iron and sea salt over the Sargasso Sea. Deep Sea Res. Part I Oceanogr. Res. Pap. 53, 547-560.

Sholkovitz, E., Sedwick, P. N., Church, T. M., Baker, A. R., and Powell, C. F. (2012). Fractional solubility of aerosol iron: synthesis of a global scale data set. Geochim. Cosmochim. Acta 89, 173-189.
Sholkovitz, E. R., Sedwick, P. N., and Church, T. M. (2010). On the fractional solubility of copper in marine aerosols: the toxicity of aeolian copper revisited. Geophys. Res. Lett. 37, L20601.

Sohrin, Y., and Bruland, K. W. (2011) Global status of trace elements in the ocean. Trends Analyt. Chem. 30, 1291-1307.

Sohrin, Y. S., Urushihara, S., Nakatsuka, T., Kono, E., Higo, T. Minami, K., etal. (2008). Multielemental determination of GEOTRACES key trace metals in seawater by ICPMS after preconcentration using an ethylenediaminetriacetic acid chelating resin. Anal. Chem. 80, 6267-6273.

Sunda, W. G., and Guillard, R. R L. (1975). The relationship between cupric ion activity and the toxicity of copper to phytoplankton. J. Mar. Res. 34, 511-529.

Sunda, W. G., and Huntsman, S. A. (1995a). Cobalt and zinc interreplacement in marine phytoplankton: biological and geochemical implications. Limnol. Oceanogr. 40, 1404-1417.

Sunda, W. G., and Huntsman, S. A. (1995b). Iron uptake and growth limitation in oceanic and coastal phytoplankton, Mar. Chem. 50, 189-206.

Trapp, J. M., Millero, F. J., and Prospero, J. M. (2010). Temporal variability of the elemental composition of African aerosol measured in trade wind aerosols at Barbados and Miami. Mar. Chem. 120, $71-82$.

van den Berg, C. M. G. (1982). Determination of copper complexation with natural organic ligands in sea water by equilibrium with $\mathrm{MnO} 2$ : I. Theory. Mar. Chem. 11, 307-322.

Wolfe-Simon, F., Starovoytov, V., Reinfelder, J. R., Schofield, O., and Falkowski. P. G. (2006). Localization and role of manganese superoxide dismutase in a marine diatom. Plant Physiol. 142, 1701-1709.

Conflict of Interest Statement: The authors declare that the research was conducted in the absence of any com mercial or financial relationships that could be construed as a potential conflict of interest.

Received: 02 May 2012; accepted: 20 September 2012; published online: 12 October 2012.

Citation: Mackey KRM, Buck KN, Casey $J R$, Cid A, Lomas MW, Sohrin Y and Paytan A (2012) Phytoplankton responses to atmospheric metal deposition in the coastal and open-ocean Sargasso Sea. Front. Microbio. 3:359. doi: 10.3389/ fmicb.2012.00359

This article was submitted to Frontiers in Aquatic Microbiology, a specialty of Frontiers in Microbiology.

Copyright (๑) 2012 Mackey, Buck, Casey, Cid, Lomas, Sohrin and Paytan. This is an open-access article distributed under the terms of the Creative Commons Attribution License, which permits use, distribution and reproduction in other forums, provided the original authors and source are credited and subject to any copyright notices concerning any third-party graphics etc. 